\title{
Examining Musical Hybridity and Cultural Influences in Valerie Coleman's Wish Sonatine and Fanmi Imèn
}

\author{
Brittany Marie Trotter \\ West Virginia University, bmt0005@mix.wvu.edu
}

Follow this and additional works at: https://researchrepository.wvu.edu/etd

Part of the Music Performance Commons

\section{Recommended Citation}

Trotter, Brittany Marie, "Examining Musical Hybridity and Cultural Influences in Valerie Coleman's Wish Sonatine and Fanmi Imèn" (2019). Graduate Theses, Dissertations, and Problem Reports. 7411.

https://researchrepository.wvu.edu/etd/7411

This Dissertation is protected by copyright and/or related rights. It has been brought to you by the The Research Repository @ WVU with permission from the rights-holder(s). You are free to use this Dissertation in any way that is permitted by the copyright and related rights legislation that applies to your use. For other uses you must obtain permission from the rights-holder(s) directly, unless additional rights are indicated by a Creative Commons license in the record and/ or on the work itself. This Dissertation has been accepted for inclusion in WVU Graduate Theses, Dissertations, and Problem Reports collection by an authorized administrator of The Research Repository @ WVU.

For more information, please contact researchrepository@mail.wvu.edu. 
Examining Musical Hybridity and Cultural Influences in Valerie Coleman's Wish Sonatine and Fanmi Imèn

Brittany M. Trotter

\begin{abstract}
A Dissertation submitted
to the College of Creative Arts

at West Virginia University
\end{abstract}

In partial fulfillment of the requirement of the degree of

Doctor of Musical Arts in

Flute Performance
Nina Assimakopoulous, Meisterklassen Podium, Chair
Matthew Heap, Ph.D, Research Advisor
Cynthia Anderson, MM
Erin Ellis, DMA
Joshua Williamson, MFA

School of Music

Morgantown, West Virginia

2019

Keywords: Valerie Coleman, hybridity, flutist-composer, flute, influences

Copyright @ 2019 Brittany M. Trotter 


\begin{abstract}
Examining Musical Hybridity and Cultural Influences in Valerie Coleman's Wish Sonatine and Fanmi Imèn
\end{abstract}

\title{
Brittany M. Trotter
}

The purpose of this research document is to examine elements of musical hybridity and cultural influences in renowned African-American flutist-composer Valerie Coleman's Wish Sonatine and Fanmi Imèn for solo flute and piano. Prominently known for her chamber music works, Coleman describes her compositional style as "urban-classical," which infuses elements of popular American styles into modern Western art music traditions to highlight and encapsulate the cultural experiences of various diasporas of our time.

The most significant elements of hybridity and cultural influences examined in Wish Sonatine and Fanmi Imèn are programmatic imagery and compositional motifs. The programmatic imagery is represented through Coleman's creation of narrative tone poems by transforming poems by Fred D'Aguiar and Maya Angelou into music. This creates a specific storyline and mood in the listener's mind. The melodic motifs serve as a compositional tool to create melody, rhythm, and harmonies that encompass influences from both inside and outside of the traditional realms of classical music. This study uses the hybridity inherent in Coleman's style to create an analytical framework to explore her works for flute and piano. 


\section{ACKNOWLEDGEMENTS}

I am extremely grateful to all those who have offered their support and encouragement throughout this degree program and specifically this research document. I offer humble gratitude to the members of my graduate committee members, Prof. Cynthia Anderson, Prof. Nina Assimakopoulous. Dr. Erin Ellis, and Prof. Joshua Williamson. Thank you for your guidance, mentorship, and teaching during my years at West Virginia University.

I would like to express a special thank you to research advisor, Dr. Heap for his unending patience, encouragement, and mentoring from the inception of this research document. I cannot thank him enough for the countless hours of insightful guidance and constant encouragement that brought this paper to completion.

To Valerie Coleman, my deepest and most sincere thanks for agreeing to this project and so graciously sharing your time and insight. I would like to also acknowledge Monica Ellis and Jonathan Page for their cooperation and help with this project.

For my mother and father, thank you for your support and spiritual guidance over the years. You have instilled in me perseverance and biblical wisdom that I can do all things through Christ who strengthened me.

Thank you to my dear friends Allyson Ricarte, Helga Scheibert, Lauretta Werner, Ruixi Niu, Jacob Kopcienski, Michael Peterson and my colleagues at the Waldorf School of Pittsburgh and Hope Academy of Music and Arts. You have been a source of joy and support.

Lastly, to my very best friend, Justin Massey, I offer my undying gratitude for your support, motivation, encouragement, and tough love which have guided me since the beginning of our journey at WVU. I cannot thank you enough for "overlooking” my moments of insanity and providing me emotional support without fail. 


\section{DEDICATIONS}

For my students - past, present and future.

You can do it. 


\section{TABLE OF CONTENTS}

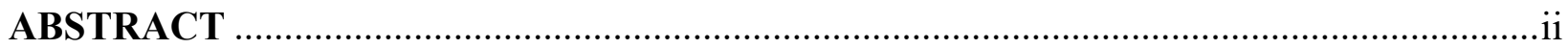

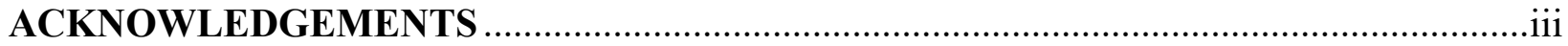

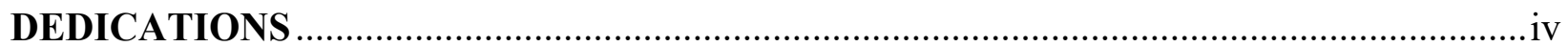

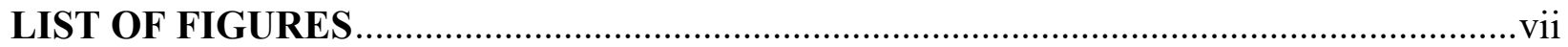

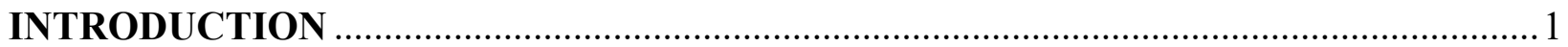

CHAPTER 1: A BIOGRAPHICAL SKETCH OF VALERIE COLEMAN ..........................

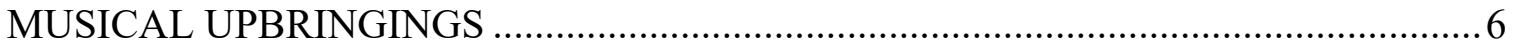

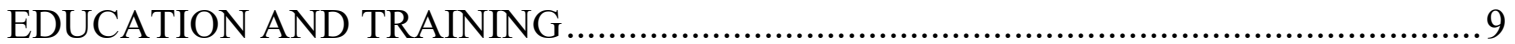

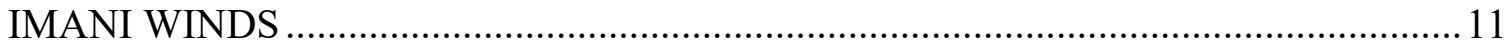

SOLO PERFORMANCE AND TEACHING …………….......................................15

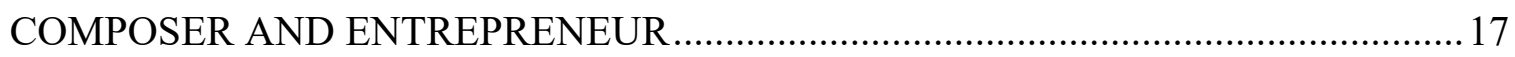

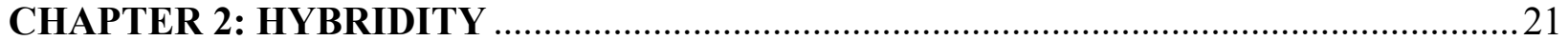

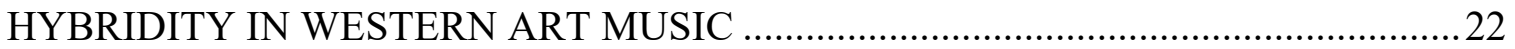

EXAMPLES OF HYBRIDITY IN SELECTED CONTEMPORARY FLUTE

LITERATURE FROM 1970 TO THE PRESENT .........................................................30

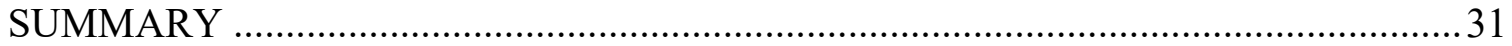

CHAPTER 3: HYBRIDITY IN THE COMPOSITIONAL APPROACH OF VALERIE

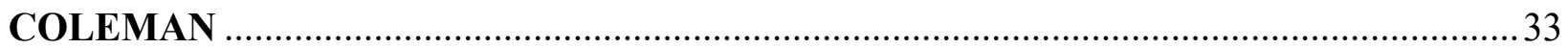

THE COMPOSITIONAL STYLE OF VALERIE COLEMAN ………...........................33

CHAPTER 4: A HERMENEUTIC ANALYSIS OF WISH SONATINE \& FANMI IMÈN. 42

BACKGROUND OF WISH SONATINE FOR FLUTE AND PIANO ............................42

ANALYSIS OF WISH SONATINE FOR FLUTE AND PIANO …………….................... 44

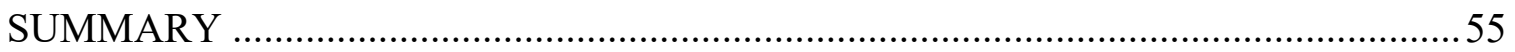

BACKGROUND OF FANMI IMÈN FOR FLUTE AND PIANO..................................55

ANALYSIS OF FANMI IMĖN FOR FLUTE AND PIANO ………............................58

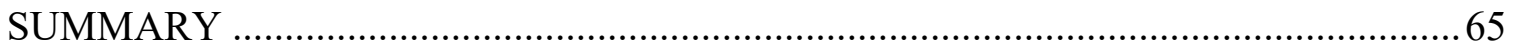

CONCLUSION

APPENDICES

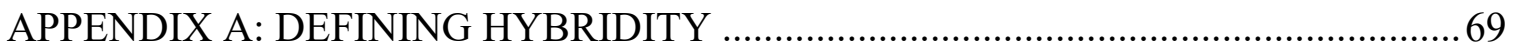

APPENDIX B: CORRESPONDENCE WITH VALERIE COLEMAN ............................76

APPENDIX C: VIDEOPHONE INTERVIEW WITH MONICA ELLIS ..........................8 80

APPENDIX D: PUBLISHED WORKS OF VALERIE COLEMAN …………………....90

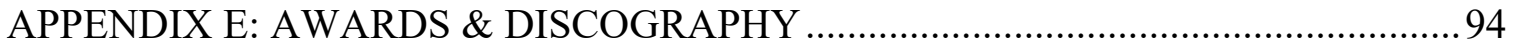


APPENDIX F: COPYRIGHT PERMISSION REQUEST: THEODORE PRESSER COMPANY …………......................................................................... 96 APPENDIX G: COPYRIGHT PERMISSION REQUEST: PENGUIN RANDOM HOUSE............................................................................................................ APPENDIX H: COPYRIGHT PERMISSION REQUEST: CARCANET PRESS LIMITED .98

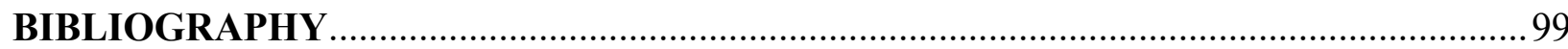




\section{LIST OF FIGURES}

Figure 4.1 - "Wish" from The Rose of Toulouse by Fred D'Aguiar .......................................... 45

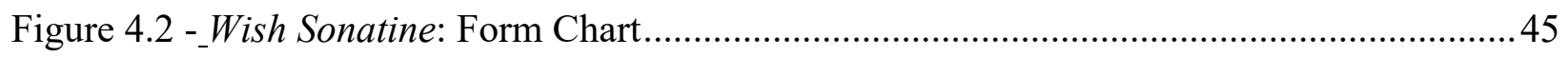

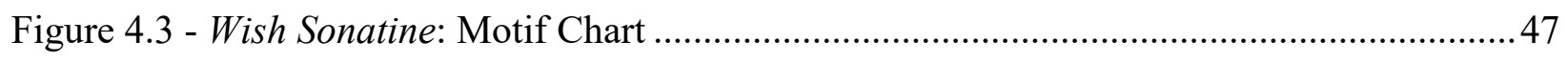

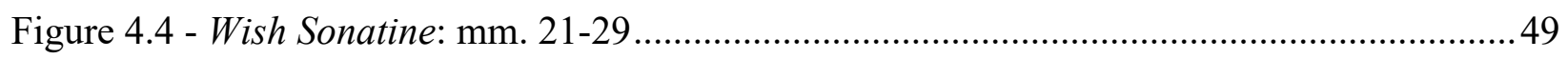

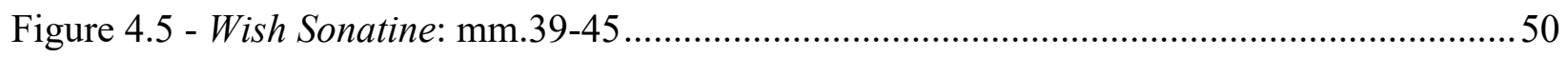

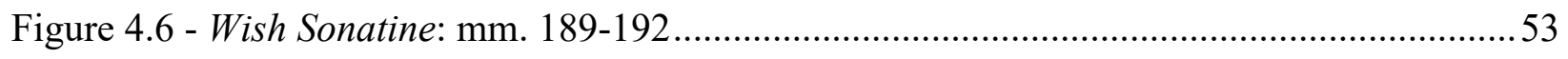

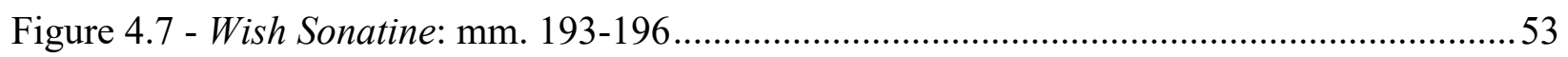

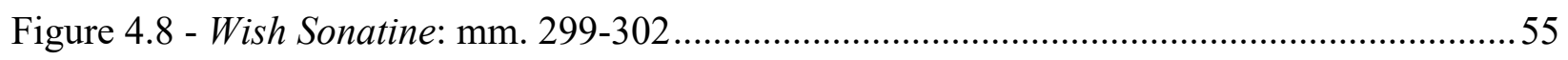

Figure 4.9 - "Human Family" from I SHALL NOT BE MOVED by Maya Angelou ...................57

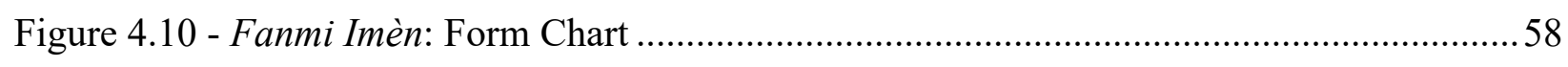

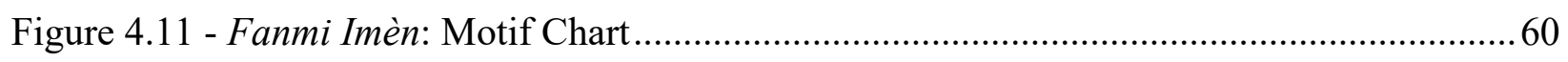

Figure 4.12 - Fanmi Imèn: Paradigmatic diagram of Fanmi Imèn motivic development............. 61

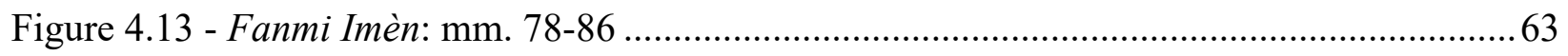

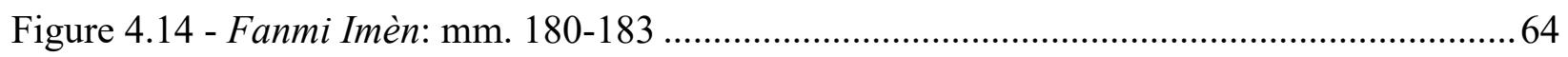




\section{INTRODUCTION}

The compositions of Valerie Coleman (b. 1970) have recently achieved profound recognition within the contemporary music circuit. Previously known primarily for her chamber compositions, Coleman's flute compositions are becoming staples of the contemporary flute repertoire through prominent performances and their use as audition material for national and regional flute competitions. She has received commissions from renowned institutions and performers such as the Philadelphia Orchestra, the National Flute Association, the Library of Congress, the Collegiate Band Directors National Association, flutist Trudy Kane, the Aark Duo, and the Flute New Music Consortium, to name a few. Coleman's popularity has produced a significant need for an academic study of Coleman's compositional style.

The focus of this document is dedicated to exploring the musical hybridity and cultural influences in Coleman's Wish Sonatine and Fanmi Imèn for flute and piano. I have chosen to research this topic in part to expand the body of scholarship about Coleman's work within the flute music community, and in part to reflect my own interest in the works of Valerie Coleman. The interest developed after listening to Coleman perform Fanmi Imèn at the 2018 National Flute Association Convention in Orlando, Fl. Coleman's performance was electrifying and left me wanting to know more about the composer and her works. Through this doctoral research document, I hope to create a framework for understanding Coleman's compositional process in order to initiate further studies of her work.

Music critics and Coleman herself have described her compositional style as "urbanclassical." The term "urban-classical" presents a hybrid of two distinct musical genres that served

\footnotetext{
1 "Works," on Valerie Coleman's official website, www.vcolemanmusic.com/about1.html.
} 
as one of the foundations of my research. Elements of popular American music, genres and styles including jazz, spirituals, and blues are heavily incorporated into Coleman's works. Furthermore, characteristic features of various musical cultures such as Middle Eastern, Asian, African, and Latin-American can be found in her music. Coleman's compositions share a common link of being drawn from inspirational sources and materials such as literary texts, timely subject matter, urban and rural landscapes, and historic figures in American history. In a written interview with the composer, Coleman describes "urban-classical" as "Something that composers who write this way always struggle to define, as it is an often-intangible characteristic of the 'classical based music of now' that infuses the cultural experiences of the Diaspora and Latinx cultures. It has elements of obstinate grooves, blues harmonies, spirituals, inflections of sorrow, influences of gospel, R\&B, Motown, and jazz."2 This fusion of musical genres and styles with cultural relevance and personal experiences demonstrates a hybridized modern musical expression which expands upon the traditional Western art music canon.

Coleman describes herself as an "intuitive" composer whose works are based on intuition and inspiration which require an investment of what she describes as "conscious and unconscious vulnerability that comes from achieving a state of flow." ${ }^{\prime 3}$ As such, I have chosen to analyze both compositions using a hermeneutic approach. American musicologist Lawrence Kramer delineates the objective of musical hermeneutics as the study of musical meaning. ${ }^{4}$ Both Wish Sonatine and Fanmi Imèn for flute and piano draw upon sources of inspiration from poetry. As such, a hermeneutic approach provides an opportunity for greater emphasis on the musical

\footnotetext{
${ }^{2}$ Valerie Coleman, interview by Brittany Trotter, written communication, November 24, 2019. ${ }^{3}$ Ibid.

${ }^{4}$ Lawrence Kramer, Musical Meaning: Toward a Critical History (Berkeley: University of California Press, 2001), 11.
} 
narration of the poem and denoting the use of musical hybridity through the various melodic motifs which unify the works.

As of this writing, there are no other academic research articles or dissertations concerning Valerie Coleman and her compositions. Although her works have been steadily gaining popularity as evidenced by her commissions from renowned institutions, less is known about her background, performances, teaching, and compositional style. Thus, I believe that this research is necessary to document Coleman's compositions and to familiarize a larger audience with her music and render a broader portrait of her artistry.

Chapter one provides general biographical information regarding Coleman's childhood, education, and career paths as both a performer and composer. Born in Louisville, Kentucky in the neighborhood of Muhammad Ali, Coleman's upbringing has remained an integral influence on her career. Providing a biographical narrative in Coleman's voice was crucial to this project, and as such I consulted previous interviews, newspaper articles, and magazine articles about Imani Winds and Coleman. Along with written correspondence with Coleman, I also corresponded with her family and colleagues. Her reflections on her thoughts and feelings during the compositional process are critical to achieving a thorough understanding of her music.

Chapter two contextualizes the term "hybridity" and presents its manifestation in Western art music history and within the contemporary flute repertoire. Broadly, "hybridity" refers to the mixture or combination of two or more distinct elements. Hybridity in music can be seen in numerous ways including borrowing, influence, allusion, quotation, emulation, texture, parody, programmatic writing, sampling, and imitation. One way that Coleman's compositional style exhibits hybridity is through her approach to blending traditional Western styles with popular American genres. This research is important because, in addition to hopefully stimulating a 
deeper conversation on the presence of hybridity in music, this document will help performers understand the diverse musical elements Coleman presents in her composition, which in turn will inform their interpretations.

Coleman characterizes her compositional process as an incredibly personal process that requires "digging deep" to allow herself to become vulnerable and quiet so that her analytical mind can "click in" and communication with her subconsciousness. ${ }^{5}$ Chapter three delves into this compositional process and highlights the various sources and materials that influence and inform her compositions. The final chapter examines Coleman's two works for flute and piano, Wish Sonatine and Fanmi Imèn. This chapter provides a hermeneutic analysis to examine programmatic imagery and compositional motifs, along with a focus on hybridity within the two works.

This research is supplemented by a compilation of reference materials including a list of published works, awards and discography, and personal interviews. A brief overview of the concepts of hybridity in culture theory and postcolonial studies is provided in Appendix A to present a broader scope of the term and justify its usage in this study. Copyright permission was granted by Theodore Presser Company for the musical examples, Penguin Random House for the text of Maya Angelou's "Human Family," and by Carcanet Press Limited for the text of Fred D’Aguiar's "Wish.”

${ }^{5}$ Coleman, interview by Trotter. 


\section{CHAPTER 1}

\section{A BIOGRAPHICAL SKETCH OF VALERIE COLEMAN}

Recognized as one of the "Top 35 Female Composers in Classical Music" by critic Anne Midgette of the Washington Post, Valerie Coleman is an internationally known and respected contemporary composer. ${ }^{1} \mathrm{~A}$ frequently performed composer, Coleman's works have been commissioned and performed by renowned orchestras and chamber ensembles such as the Philadelphia Symphony Orchestra, San Francisco Chamber Orchestra, Brooklyn Philharmonic, Hartford Symphony Orchestra, and Harlem Quartet. ${ }^{2}$ Her compositions are accessible to a variety of audiences due to what critics describe as her "urban-classical" style of blending modern Western orchestration and techniques with popular urban genres including jazz, spirituals, and blues. Coleman also brings a sense of cultural relevance into her compositions by often drawing inspiration from the words and biographies of historical figures and writers such as Langston Hughes, Maya Angelou, and Josephine Baker, to name a few.

Before exploring elements of musical hybridity and identity in Coleman's compositions, I will highlight Coleman's musical development and offer a glimpse into the materials and people that inspire, influence, and inform her compositional writing. As a sought-after performer, composer, academic professor, entrepreneur, and arts advocator, her musical and professional activities are both diverse and far reaching. Coleman's influences and legacy are visible in professional music journals and major news media. A Grammy® nominated flutist, she has been

\footnotetext{
${ }^{1}$ Anne Midgette, "The Top 35 Female Composers in Classical Music," The Washington Post, August 4, 2017, https://www.washingtonpost.com/entertainment/music/the-top-womencomposers-in-classical-music/2017/08/04/319274d4-76f2-11e7-803f-a6c989606ac7_story.html. ${ }^{2}$ Valerie Coleman, "Biography," on Valerie Coleman's official website, accessed October 30, 2019, www.vcolemanmusic.com/about.html.
} 
reviewed extensively in the New York Times, The Washington Post, The Philadelphia Tribune,

The Boston Globe, Los Angeles Times, NPR, and The Flutist Quarterly, for her compositions and performances which are regularly aired nationally on public broadcasting radio and abroad via Sirius XM, PBS, the Australian Broadcast Company, and Radio NZ.

Studying a living composer has allowed for me to receive commentary directly from Coleman in her own words. Too often in research documents, personal details of the composer's life are left to speculation, potentially resulting in questionable and erroneous accounts. With the intention of collecting valuable insights into the composer, much of the research presented in this document makes extensive use of personal accounts from the composer's close relatives, colleagues, and also includes previous interviews given by Coleman herself. In an effort to keep their voices authentic and true to their identity, I intentionally quote them in their colloquial dialect rather than imposing formal grammar. Along with my personal observations, I hope that using this patchwork of voices will create a compelling picture of the composer.

\section{MUSICAL UPBRINGINGS}

Coleman's intimate relationship with music started before birth. According to Coleman, her mother would play recordings of Beethoven's Sixth Symphony and Pastoral Symphony while she was in the womb. ${ }^{3}$ Valerie Coleman was born in Louisville, Kentucky on September 3, 1970. She was raised in the same west-end inner city neighborhood in Louisville as acclaimed American professional boxer Muhammad Ali. At the age of nine, Coleman's father passed away, leaving her mother to raise Coleman and her two older sisters as a single parent. Describing the

\footnotetext{
3 "Women's History Month Spotlight: Valerie Coleman," University of Miami News, March 7, 2019, https://news.miami.edu/frost/stories/2019/03/valerie-coleman-womens-month.html.
} 
resilience of her mother, Coleman recalls, "she raised me right, and she worked hard at it....my mom became a single mom at that point and she picked up the pieces."4

A child-care worker, Coleman's mother owned and managed a daycare center in their family home. A "quintessential educator," Coleman credits her mother for intuitively nurturing her artistry as a young child. ${ }^{5}$ Describing both her mother and her experiences living in a daycare, Coleman states, "There was always something to do at the daycare. What is great about my mother is her desire for kids to have a safe space to explore to be either scientists, artists, or musicians and to learn how to communication. Her love to let a child's mind unfold and grow allowed for my creativity to take a front row seat in my development."6

Coleman's interest in flute and composition began at an early age, before any formal musical training. As a child, Coleman would pick up tree limbs in her backyard and pretend she was playing the flute. In the same playful fashion, Coleman's interest in composition started with her playing on her mother's Hammond electric organ. For Coleman, composing was synonymous with creativity, stating, "I have always been into composing, but I cannot exactly pin point when it began. It is like when you meet a really good friend and you cannot remember exactly that moment when you met. But I do remember being a young kid playing a cheap Hammond organ in my mother's house. I guess in a way, there was never a moment where I felt

\footnotetext{
${ }^{4}$ Valerie Coleman, "Classical Chamber Music Ensemble Imani Winds," interview by Ed Gordon, NPR News \& Notes, May 23, 2006, https://www.npr.org/templates/story/story.php?storyId=5425259.

${ }^{5}$ Heidi Kay Begay, "An Interview with Valerie Coleman," December 8, 2018, in Flute 360, episode 37, podcast, 40:33, http://heidikaybegay.libsyn.com/episode-37-an-interview-withvalerie-coleman.

${ }^{6}$ Ibid.
} 
that creativity was something I had suddenly decided to do since it has always been a part of my playtime." 7

Coleman's enthusiasm for composing soon developed into a curiosity about how to document her composition. At the age of 9 , she started to experiment with ways to record and notate the tunes she created on her family organ. Coleman recounts her earliest attempts at documentation in an interview stating,

The Hammond electric organ had an old cassette tape playback feature. I would play the melody on one cassette tape. While the original recording was looping, I would record another layer. Looking back now, the quality of the recording was truly hideous due to the bad intonation of the warping sound of the cassette player, but to a nine-year old, it was the greatest thing in the world. After a while, I think it just gotten to a point where I was like this need to be written down. So, I had created my own notation because, at the time, I have not picked up the flute just yet and I did not know how to read music. I used boxes and triangles to mimic the pitches and rhythms of my compositions. So, I could not wait to learn notation and pick up that throughout elementary and middle school. ${ }^{8}$

Coleman's enthusiasm for composing continued simultaneously as she started to play the flute in her fourth-grade band program. By the age of fourteen, Coleman had written three symphonies and won several local and state performance competitions. For Coleman, learning the flute and composing have always been analogous with each other. She recalls, "I was eager to learn scales as a flutist because it informed my writing process through melodies and things like that."

Coleman's early success as a young flutist led her to perform with the Louisville Youth Orchestra. While there, Coleman remembers Robert Sirota, director of Boston University's School of Music, auditioning members of the Louisville Youth Orchestra for the Tanglewood Institute summer program. Without much preparation, Coleman auditioned for him on flute and

\footnotetext{
${ }^{7}$ Ibid.

${ }^{8}$ Ibid.

${ }^{9}$ Begay, “An Interview with Valerie Coleman,” December, 8, 2018.
} 
piccolo and, a few weeks later, she received a scholarship award letter to attend Tanglewood in Lenox, MA. ${ }^{10}$ As one of her first experiences outside of Kentucky, the Tanglewood Institute left a huge impression on Coleman's aspiration to be a flutist and composer. Coleman continued to attend Tanglewood Institute in the following years, where she studied with Doriot Dwyer and Leone Buyse, and various other summer music festivals including the Aspen Music Festival where she studied with Mark Sparks. After graduating from Louisville Male Traditional High School, she attended the University of Kentucky on a full scholarship. After studying there for a semester, Coleman realized she needed to fulfill her passion for composing as well. Disheartened that the program did not offer a bachelor in composition, Coleman transferred to Boston University where she could double major in flute performance and composition. ${ }^{11}$

\section{EDUCATION AND TRAINING}

As an undergraduate student at Boston University, Coleman studied flute with Alan Weiss, Doriot Dwyer and composition with Marin Amlin. Highly successful during her studies at Boston University, Coleman received several distinctions and awards including being a two-time laureate of the Young Artist Competition, winning the Woodwinds Awards, and receiving the Aspen Music Festival Wombwell Kentucky Award. After graduating from Boston University with Bachelor of Flute Performance and Bachelor of Composition and Theory degrees, Coleman decided to move to New York for graduate studies in flute performance, taking a step back from

\footnotetext{
${ }^{10}$ Joel Brown, "Once a BU Tanglewood Institute Student, Alum Valerie Coleman Returns as Visiting Artist," BU Today, July 16, 2019, http://www.bu.edu/articles/2019/once-a-butanglewood-institute-student-alum-valerie-coleman-returns-as-visiting-artist/.

${ }^{11}$ Peter Westbrook, "Valerie Coleman: Revitalizing the Woodwind Quintet," Flutist Quarterly vol. 33, issue 3 (Spring 2008): 37.
} 
her composition aspirations. ${ }^{12}$ In an interview with New Music USA, Coleman describes her inner dueling duality between being a flutist and composer, expressing that she did not consider herself to be a composer after graduating from Boston University. She states,

I was so disenchanted with the snobbish elitism of the composer community there, as it was clear that there was no room for someone of my cultural background or creative process. There was a constant climate that narrowed the ideas of what is and is not valid for the identity and writing styles of being a composer. I did not and could not identify with that. So, there was always that fight about what a composer is, and what the stereotype is that I just was not attracted to at all. But when I came to New York, I realized that composers define themselves in a different way. So whereas Boston University was my first introduction to this concept of composer and put it in a box, New York opened it up. ${ }^{13}$

Coleman attended the Mannes School of Music in New York City for a Master's of Music in flute performance, where she studied with Judith Mendenhall. While in school, Coleman continued her composition studies with Randall Woolf.

As a student at Mannes, Coleman began to conceive an idea to form a woodwind quintet. In an interview, Coleman recounts how her idea originated, stating, "It's so funny. A friend of mine told me once that I had been talking about forming a woodwind quintet of people of color way back then. And I don't remember any of that. Maybe it was all just talk, because I am one hell of a dreamer ---I can just dream, dream, dream all day. But it wasn't until I got up here to New York, to do my graduate work at the Mannes school, that the idea of the name Imani Winds popped into my head." ${ }^{14}$ Starting with the name Imani, based upon the seventh day of Kwanzaa and meaning "faith" in Swahili, Coleman envisioned forming a chamber group that brought together five people of color and used their backgrounds as a means of interpreting music of

12 Valerie Coleman, "Biography," on Valerie Coleman's official website, accessed October 30, 2019, www.vcolemanmusic.com/about.html.

${ }^{13}$ Imani Winds, "Imani Winds: Terra Incognita," interview by Frank J. Oteri, New Music Box, July 15, 2010, https://nmbx.newmusicusa.org/imani-winds-terra-incognita/.

${ }^{14}$ Westbrook, "Valerie Coleman," 37. 
various eras, from Mozart to contemporary music. Coleman also recognized the opportunities that starting a chamber group could have in assimilating her artistry as a flutist and composer and also in securing financial stability or, as Coleman puts it, "a way to pay back my student loan."15

\section{IMANI WINDS}

In 1997, Coleman started her search for musicians to join Imani Winds by cold-calling music schools such as Julliard and the Manhattan School of Music. In recalling the events that eventually unfolded into a long-standing relationship between her and her future collaborators, Coleman remarks,

I basically called around. I gave them my whole spiel. One of the things that I asked them was when you were growing up, who were your role models? And, were there any AfricanAmericans as your role models? And the answer was basically no from everyone. Of course, you had Winton Marsalis, but he plays trumpet and we're woodwind instruments. So, I said, well, guys, we have a chance to change that. We really have the opportunity to let people know that classical music is an all-inclusive thing, not exclusive. That's basically how the group came together. We get into a practice room. It was magic from the very beginning, and I said to myself, this is going to be something. ${ }^{16}$

Coleman's recruitment efforts resulted in the formation of Imani Winds comprising of herself as flutist, oboist Toyin Spellman-Diaz, bassoonist Monica Ellis, clarinetist Mariam Adam, and hornist Jeff Scott. At the time, Toyin, Monica, and Mariam were students at the Manhattan School of Music, and Jeff, who had graduated, was a pit musician for the Broadway production of The Lion King. ${ }^{17}$ Although inspired by other successful wind quintets such as the Dorian Wind Quintet, Imani Winds set out to establish themselves as unique. Along with performing standard repertoire, the ensemble advocated for more new and diverse works in the classical chamber

${ }^{15}$ Valerie Coleman, "FNMC Presents: Interview with Valerie Coleman," interview by Karen Large, Flute New Music Consortium, video, 18:59, November 17, 2018, https://www.youtube.com/watch?v=t-ZUu86SP-8.

${ }^{16}$ Coleman, "Classical Chamber Music Ensemble Imani Winds," interview by Ed Gordon.

${ }^{17}$ Imani Winds, "Imani Winds: Terra Incognita," interview by Frank J. Oteri. 
winds canon. Searching for new work became a mission and a necessity for the ensemble due to the small amount of literature written for the wind quintet. As Ellis states,

When it comes to repertoire, if you're going to sustain yourself like we have, you absolutely have to have something else more than just standard stuff that's out there, because you'll finish the repertoire in two or three concerts. And then, what do you do next? So, there are people in the group writing for us. And then finding other pieces that are already out there, because sometimes there are wonderful pieces. You just have to unearth them. There're just not really known amongst the greater population. That the part of the problem too. ${ }^{18}$

Considering the relatively small catalog of chamber wind quintet literature, Imani Winds had the unique attribute of originally having two resident composers in the ensemble. Hornist Jeff Scott and Coleman contributed several works for the group over the first several years, providing lively and refreshing works that explored the African/Latin heritage of the virtuosic ensemble members. Imani Winds provided Coleman with opportunities to workshop finished and unfinished pieces, a luxury that she comments about frequently in interviews. "I think part of her writing process was to utilize us," Ellis remarks, "When you have a group, you bring in tunes. You bring in stuff. Everyone is contributing. Its might not be something that you play tomorrow, but it would be later."19

Imani Winds received relatively early success, including winning a few small competitions. Recognizing their potential as a premiere professional ensemble, the members decided to pursue Imani Winds full time in 2000. The ensemble gained notable success in 2001 when they won the Concert Artists Guild Victor Elmaleh Competition, which provided them with two years of management and awarded them the title of Educational Residency Ensemble. Imani Winds continued to receive other accolades including a three-year residency with the Chamber Music Society of Lincoln Center, ASCAP's Award for Adventurous Programming, and

\footnotetext{
${ }^{18}$ Ibid.

${ }^{19}$ Monica Ellis, interview with Brittany Trotter, October 29, 2019.
} 
appearances in major concert halls throughout the United States. The ensemble went on to record a total of five albums from 2002-2010. Their first album, Umoja, won the CMA/WQXR recording award, their second album, The Classical Underground, received a Grammy nomination for Best Classical Crossover Album in 2006, and their fifth album, Terra Incognita, was named by NPR Music as one of the "5 Best American Contemporary Classical Albums of 2010." 20

Committed to championing an array of diverse composers who are underrepresented in the Western canon, Imani Winds created a collaborative commissioning project, the Legacy Commissioning Project, with artists such as Roberto Sierra, Stefon Harris, Simon Shaheen, Paquito D'Rivera, Wayne Shorter, and Mohammed Fairouz. As an ensemble with members of African-American and Latino background, Imani Winds has expressed in several past interviews the importance of their heritage be represented in the music that they play and in the musicians they commission, as Ellis states,

So even though we've gone after composers that we'd label unrepresented, at least for the wind quintet, we do want to have this kind of balance occur, which is have them be represented as African-American, Latino composers writing for an African-American, Latino group. At the same time, let their music speak for itself. We also realized through the Legacy Commissioning Project that collaborating with jazz artists would be a fabulous thing to do, since we're kind of joining in so many different types of players and thoughts and musicians, people that have written for all facets of every kind of musician, people that have written for all facets of every kind of music. Let's look at really almost straight-ahead jazz players and what their perspective would be for writing for a wind quintet, writing for a classical-in all regards, most regards- type of group. And that has led to so many other types of platforms and landscapes of sound. ${ }^{21}$

20 "Biography" on Imani Winds official website, accessed November 27, 2019, http://www.imaniwinds.com/bio.

${ }^{21}$ Imani Winds, "Imani Winds: Terra Incognita," interview by Frank J. Oteri.

${ }^{21}$ Ibid. 
Over the past decade, Imani Winds has maintained an extensive touring schedule that averages some 200 concerts a year both nationally and internationally, including solo and collaborative performing with popular artists like saxophonist Steve Coleman, pop-artist Morley, jazz singer Cassandra Wilson, and trumpeter Wynton Marsalis. Along with creating and commissioning new music, Imani Winds also sought out creative projects that highlight and strengthen the rich diversity of chamber music through mentorship. In 2009, the ensemble created the Imani Wind Chamber Music Festival (IWCMF) as both an institute and chamber music series on the Lincoln Center Campus in New York City. ${ }^{22}$ IWCMF attracts young artists from across the globe to receive mentorship from Imani Winds in exploring different paths of chamber music performance and repertoire. The ensemble participates extensively in educational residencies and master classes for thousands of students each year at numerous academic institutions including being the ensemble in residence at the Mannes College of Music, the Banff Chamber Music Intensive, and the University of Chicago. ${ }^{23}$

Although the personnel of the ensemble have changed, Imani Winds has remained a tour de force for over two decades. Their contributions have expanded beyond the classical music world and have invited historical recognition, including a permanent presence in the classical music section of the Smithsonian's National Museum of African American History and Culture in Washington, DC. On October 1, 2018, Valerie Coleman announced her retirement from Imani Winds. In a Facebook post, Coleman explained her decision to retire stating,

The decision came from a simple prayer: to be fully become who I am meant to be as an artist, and from my work, inspire others to grow. That prayer was answered in short order with a hurricane. A series of life changing moments and opportunities came that made me realize that I had to make a choice in whether or not to take a risk and walk a different path

22 "About" on Imani Winds Chamber Music Festival official website, accessed November 27, 2019, http://www.imaniwindsfestival.com/about.

23 "Biography" on Imani Winds official website. 
as an artist, beyond the comforts of routine and stability that comes from being in what I believe is one the greatest chamber music ensembles of our time. ${ }^{24}$

Coleman continues to profess the values and innovative ideas she created in founding Imani Winds. The ensemble continues to be her "baby," and its past, present, and future can only be beneficial to flutists and non-flutists alike. ${ }^{25}$

\section{SOLO PERFORMANCE AND TEACHING}

Coleman's path as a celebrated chamber musician and composer is distinct from her solo career. Prior to making her flutist-composer debut at Carnegie Hall in 2004, Coleman understudied for Eugenia Zukerman at Lincoln Center and was featured as a soloist in the Mannes 2000 Bach Festival. ${ }^{26}$ In addition to being showcased on the New York classical radio station WQXR, she has performed at numerous venues such as Carnegie Hall, the Lincoln Center, the Kennedy Center, and at Alice Tully Hall. Coleman recognizes that her career goals used to be along "the soloist/orchestra track, but I knew that being an instrumentalist means wearing so many hats; you can't just be one thing."27

Another role which Coleman successfully inhabits is that of teacher. Her past positions include being on the faculty at Julliard's Music Advancement Program, InterSchool Orchestras of New York, and the Chamber Music Society of Lincoln Center's Teaching Artist Program. In August 2018, Coleman was appointed Assistant Professor of Performance, Chamber music, and

\footnotetext{
${ }^{24}$ Valerie Coleman (VC Page), "Dear FB friends and family, I have big news to share," Facebook post, October 1, 2018, https://www.facebook.com/VALERIECOLEMANPAGE/posts/10155876025086033.

${ }^{25}$ Westbrook, "Valerie Coleman," 37.

${ }^{26}$ Ibid., 37.

${ }^{27}$ Ibid., 37.
} 
Entrepreneurship at the University of Miami's Frost School of Music. Coleman said of this

tailor-made position,

So, what happened was I got the call from the Dean and he basically offered the position and I said, so what exactly does it entails? And he said, anything you like. And I am thinking this could be really cool, it could go really well or it could go really wrong because you have a position that does not really have shape to it. You have to really work to not only create the job description itself, but also work with others in a way that inform them what is possible. So, it is not just me that needs that kind of structure, but everybody else that is working with me as well. ${ }^{28}$

With her teaching duties at the University of Miami, Coleman continues to maintain her

strong advocacy for diversity in the arts and remains a source of inspiration to emerging artists.

In commenting about one of the specific ambitions she intends to achieve in her position,

Coleman states,

I love chamber music. And there is a lot of offer, but there is also a lot going on at the University of Miami's Frost School. It seems that chamber music could use a little more TLC. It is going great as it stands, but I think I have something to add to the whole fiber and culture. To create a culture of chamber music is what my goal is there. [In regards to the entrepreneurship component], And having the wherewithal in how to structure your career, to be able to plan it in advance, to be able to know how to network, all of those things is something that I really am passionate about. I love to see these students when they go off, take the initiative and become entrepreneurs. It's the best." ${ }^{29}$

A sought-after clinician, Coleman has presented masterclasses at colleges and has also been a guest artist and recitalist in various regional and national flute conventions. Coleman continues to advocate and mentor emerging artists and ensembles. Currently serving on the board of advisors for Composers Now, the MacDowell Colony, and Sphinx LEAD, she has previously served on the Association of Performing Arts Professionals' Classical Connections Committee,

${ }^{28}$ Caity Massoud, "Valerie Coleman," January 15, 2019, in Flute Unscripted, podcast, MP3 audio, 30:55, https://player.fm/series/flute-unscripted/valerie-coleman.

${ }^{29}$ Ibid. 
and the National Flute Association's New Music Advisory Committee and Board Nomination Committee. $^{30}$

\section{COMPOSER AND ENTREPRENEUR}

The title of flutist-composer is boldly promulgated on Valerie Coleman's personal website. At a glance, one could speculate that the title refers to a musician who is primarily a performer, yet engages in composition or improvisation as a way to express some of their musical ideas. ${ }^{31}$ Although Coleman certainly exhibits this trait, she envisions the function of flutist-composers to involve a high level of cohesion between the two roles. Monica Ellis compares Valerie's duality to that of a jazz musician, stating,

When you think about it, people simply do not ask jazz musicians the questions of "Are you more of a composer than a performer?" People don't ask jazz musician that because they write music all the time. They are improvisors who are constantly writing all the time. There is a spirit of composing within the world of improvising. With Valerie, I think she lives categorically in that lane than classical because she does say there is a distinct duality. She doesn't consider herself as just a flutist or a composer. It is absolutely, $100 \%$ both. $^{32}$

As resident composer and flutist of Imani Winds, Coleman composed and performed her works and arrangements for chamber winds in renowned concert halls both nationally and internationally. Among the 12 chamber works she has written and arranged for the group, Coleman's Umoja, named after the Swahili word for "unity," is highly recognized as the ensemble's signature piece which they perform at almost every performance and was listed by Chamber Music America as one of the "Top 101 Great American Ensemble Works." 33 Being a

30 "Biography," on Valerie Coleman's official website.

31 In reference to the definition of performer-composer in Carol Gertrud Isaac, "The solo flute music of three contemporary flutist/composers: Robert Aitken, Robert Dick, and Harvey Sollberger," (DMA diss., University of California, 1991), 19.

${ }^{32}$ Ellis, interview with Trotter.

${ }^{33}$ Coleman, "Classical Chamber Music Ensemble Imani Winds," interview by Ed Gordon. 
flutist also informs the way Coleman writes for the instrument. In the interview with Ellis, she remarked on the experiences she and Coleman had when Imani Winds was reading through various composers works and often finding that there was simply not enough direction in terms of phrasing or articulation written by the composer. "I think that experience helped her to write clearly so her point [musical ideas] would come across more efficiently." Ellis states, "Having all the ingredients on the page is important and, as a composer, she does that really well."34

In addition to her chamber works for wind quintet, she has written numerous works ranging from pieces for solo instruments to concert band and orchestral works. Coleman's eclectic style has been recognized through commissions including from the American Composers Orchestra, the Collegiate Band Directors National Association and the National Flute Association, to name a few. On September 19 ${ }^{\text {th }}, 2019$, the Philadelphia Symphony Orchestra premiered Coleman's commissioned work, Umoja, Anthem for Unity, at the Kimmel Center's Verizon Hall in Philadelphia, PA with a second performance at Carnegie Hall in New York, NY. The commission by the Philadelphia Symphony Orchestra marks their first ever performance of a classical work by a living African-American female composer. Transcending boundaries is not surprising for Coleman whose compositions have received critical acclaim. Coleman has received many awards and commissions which recognize her achievement as a composer including the Herb Alpert Award in the Arts' Ragdale Residency Prize, and her chamber work UMOJA was listed as one of the "Top 101 Great American Ensemble Works" by Chamber Music America, among many others.

In addition to her compositional success, Coleman is also a modern-day musicianentrepreneur. As the founder of Imani Winds, Coleman conceived of many projects including the

34 Ibid. 
Legacy Commissioning Project and the Imani Winds Chamber Music Festival that were also supported by the other members in the ensemble. Approximately twenty years later, Coleman continues to envisage projects that connect people to music and advocate for diversity in the arts. She is involved in several performance projects including Umama Womama, a composers' collective performance ensemble featuring violist Nokuthula Ngwenyama, Harpist Hannah Lash, and herself on flute, and The Flute Speakeasy Intensive, a workshop for aspiring performercomposers of all levels seeking encouragement and tips from composers Amanda Harberg, Nicole Chamberlain, and Coleman. Coleman's future projects include commissions by flutist Trudy Kane and the Flute New Music Consortium backed by their over 60 contributing commissioning members. In similar fashion to her flutist-composer contemporaries, Coleman publishes and distributes her compositions through her own company, named V Coleman Music, along with music publishers Theodore Presser and International Opus. Despite recently settling into the second phrase of her career, Coleman is richly cultivating the fruits of her labors.

Given the array of musical activities in which Coleman engages, it is natural to consider her compositions from the viewpoint of hybridity. Critics have heralded Coleman's music as "living mosaics that connect...culture and humanity," through her blending of traditional classical sonorities with sounds that encompass the diverse modern culture of America, creating a shared experience. ${ }^{35}$ The next chapter explores the concept of hybridity and its manifestation in Western art music. This chapter provides justification for applying "hybridity" to Coleman's

35 "Works," on Valerie Coleman's official website, accessed November 27, 2019, Coleman, "Classical Chamber Music Ensemble Imani Winds," interview by Ed Gordon. 
compositional approach. A further overview of the origins of hybridity within the context of postcolonial studies and culture theory is provided in the appendix to this document. 


\section{CHAPTER 2}

\section{HYBRIDITY}

In its simplest sense, hybridity refers to the process or results of mixing or "crossing two or more races, languages, identities, objects, or other clearly bounded elements." ${ }^{1}$ Originally associated with biology, its meaning within the humanities has been contested due to its problematic association with race. ${ }^{2}$ Given the current trends of modern Western society towards tolerance and multiculturalism, the popular discourse on hybridity now commonly characterizes the term as progressive, alliance-building, anti-imperialist, and subversive. ${ }^{3}$ Artists and scholars could understand the concept of hybridity in music using the ideas of musical mixing, merging, melting, influences, and borrowing, which have a long history in Western art music. From the 1960 's to the present, musicologists and ethnomusicologists have considered the use of hybridity in music to be a gesture of fascination and intrigue by composers. ${ }^{4}$ By combining elements such as old and new styles, Western and non-Western music, and drawing inspiration from literature, composers continue to create works that have contributed to a hybrid musical language and compositional style.

In order to explore the concept of hybridity in the selected flute works of AfricanAmerican composer and flutist Valerie Coleman, I will first examine the contextual usage of

\footnotetext{
${ }^{1}$ Bruno Moschine Alcalde, "Patterns of Hybridity: An Analytical framework for Pluralist Music" (PhD diss., Northwestern University, 2017), 21.

${ }^{2}$ For further explanation, please refer to Appendix A.

${ }^{3}$ Michael Syrotinski, "Hybridity Revisited," in Deconstruction and the Postcolonial: At the Limits of Theory (Cambridge: Liverpool University Press, 2017), 26.

${ }^{4}$ Georgina Born and Hesmondhalgh, David, Western Music and Its Others: Difference, Representation, and Appropriation in Music (Berkeley: University of California Press, 2000):8 and Postcolonial Studies @ Emory, "Hybridity and Postcolonial Music," by Yim Tan Lisa Wong, posted Fall 1997, last edited October 2017, https://scholarblogs.emory.edu/postcolonialstudies/2014/06/20/hybridity-postcolonial-music/.
} 
hybridity and its manifestation in Western art music. Then I will address the concepts as found in contemporary flute repertoire. The following literature review offers a way to integrate the different usages of hybridity into a framework to bridge the connections in music performance studies.

\section{HYBRIDITY IN WESTERN ART MUSIC}

Hybridity has been a popular idea in various academic disciplines, particularly within the social sciences and humanities. The discourse about it has long influenced musicology's contextual application of musical hybridity. For instance, one of the most influential scholars in the concepts of hybridity within postcolonial studies is Homi K. Bhabha, whose analysis of hybridity explores what he describes as a "third space." ${ }^{5}$ As Bhabha describes, "...the importance of hybridity is not to be able to trace two original moments from which the third emerges, rather hybridity to me is the "third space" which enables other positions to emerge."" Basically, the third space implies a gap between colliding cultures that allows a blurring of existing boundaries and causes a disruption of established categorizations of culture and identity. One could draw a parallel between Bhabha's theory of the third space and the concepts of crossing musical boundaries and hybrid identities in various compositional styles.

Without specifically referencing Bhabha, twentieth and twenty-first century composers have metaphorically used the concept of the third space to defend their use of borrowed

\footnotetext{
${ }^{5}$ Postcolonial studies is an academic branch of the humanities discipline which studies the cultural legacy of colonialism and imperialism and its implications of control and exploitation of colonized people and their land. Reference to Katarzyna Marciniak, "The Postcolonial And The Postmodern: Homi Bhabha.” Accessed September 15, 2019, http://homepage.westmont.edu/hoeckley/readings/symposium/pdf/201_300/218.pdf.

${ }^{6}$ Sheila Benson, "'I Don't Know If That'd Be English or Not': Third Space Theory and Literacy Instruction," Journal of Adolescent and Adult Literacy 53, no. 7 (April 2010): 555-556.
} 
American jazz idioms in Western classical works. For example, Maurice Ravel explains his incorporation of this American popular art form in his remarks on contemporary music at Rice in 1928 stating,

"While I adopted this popular form of your music, I venture to say that nevertheless it is French music, Ravel's music, that I have written. Indeed, these popular forms are but the materials of constructions, and the work of art appears only on mature conceptions where no detail has been left to chance. Moreover, minute stylization in the manipulation of these materials is altogether essential... Think of the striking and essential differences to be noted in the "jazz" and "rags" of Milhaud, Stravinsky, Casella, Hindemith, and so on. The individualities of these composers are stronger than the materials appropriated. They mold popular forms to meet the requirements of their own individual art. Again- nothing left to chance; again - minute stylization of the materials employed, while the styles become as numerous as the composer themselves."

Ravel did not consider his music to be a fusion of French music and jazz music, but rather a new identity that he created in his composition. This has prompted criticism from modern music scholars over Ravel's and other prominent composers' conscious and unconscious appropriation of marginalized or non-Western musical cultures. While a thorough investigation of appropriation is outside the scope of this document, I recognize that it is a much-discussed topic within the musical community and will include further discussion about twentieth and twenty-first century composers' use of non-Western and popular music within Western art music later in this chapter. Nevertheless, this research focuses on analyzing the formulation of hybridity in the music of Valerie Coleman, which comes from personal experience rather than appropriation.

If we are to believe the metaphorical adage that music is a universal language, it would be critical to denounce the assertion that there can be purity within any musical style. Hybridity

7 Maurice Ravel, "Contemporary music." Rice Institute Pamphlet - Rice University Studies 15, no. 2 (1928): 140. 
within the context of Western art music is most commonly derived from borrowings and exchanging across boundaries such as the "East" and "West." It is the degree of influence by or reference to other non-Western music that lured music scholars in the field of musicology and ethnomusicology to analyze composers' attempts to renew their musical language with a new hybrid source of influence. Given the breadth of this research, I will selectively provide examples of recent and influential scholarly writing that highlight the different types of hybridity found in Western music in order to demonstrate its prevalence across several centuries rather than embark upon a complete literature review.

Building upon the research of works dealing directly with the notions of exoticism and orientalism, Ralph Locke (2012) and Jan Pasler (2006) examined the intent and function of Eastern musical influence within the works of twentieth-century composers. ${ }^{8}$ Using postcolonial concepts, Locke analyzed various twentieth-century operas in terms of recurring structures of plot and characters and the compositional style employed by the composers to represent their imagination of the East. Similarly, Pasler deconstructs race relations during the late nineteenthcentury in France and their contribution to various racial myths of French identity and music.

In contrast, Georgina Born and David Hesmondhalgh (2000) investigate the intricate musical relationship between Western art music and "other" music. ${ }^{9}$ Attempting to answer the questions of the appropriateness of musical borrowings and appropriation, Born and Hesmondhalgh address the difference and alterity in music through the lenses of colonialism, imperialism, and globalization. Through these concepts, the authors illustrate the individual

${ }^{8}$ See Ralph Locke, "On Exoticism, Western Art Music, and the Words We Use." Archiv Für Musikwissenschaft 69, no. 4 (2012): 318-328, and Jann Pasler, "Theorizing Race in NineteenthCentury France: Music as Emblem of Identity." The Musical Quarterly 89, no. 4 (2006): 459-504. 9 Georgina Born and Hesmondhalgh, David, Western Music and Its Others: Difference, Representation, and Appropriation in Music (Berkeley: University of California Press, 2000), 2. 
qualities of musical constructions of the other, the function of a composer's musical imagination and the wider issues of cultural representation and identity through music.

Like Born and Hesmondhalgh, Timothy Taylor (2004) explores Western musical domination in terms of imperialism, colonialism, and globalization. ${ }^{10}$ Taylor deals specifically with modern popular world music and illustrates the ways that the concepts of hybridity and the discourse about hybridity have affected the interpretation of the listener, performer, and composer. In contrast Taylor argues that, due to the era of globalization, non-Western musicians who make world music are still consigned to the "other" despite their use of hybridity of Western elements that allows them to be constructed as authentic.

Western music has clearly exhibited traits of mixture and interaction of musical identities that are primarily associated with groups or individuals for hundreds of years. Compositional techniques that contribute to musical hybridity include, but are not limited to, borrowing, influence, allusion, quotation, emulation, texture, parody, programmatic writing, sampling, and imitation. This wide array of terms reflects forms of hybridity and appropriation in music which can assist performers to recognize specific cultural musical references and inform their musical interpretation. Examples of different types of compositional musical hybridity can be seen in various works dating from around the 1400 s to the present day.

The use of imitation was popular during the Renaissance period dating around 14001600 s, due to the constant travel of composers and their awareness of international styles. Composers emulated each other by appropriating entire cantus firmi, which created a sense of

${ }^{10}$ Reference to Timothy D. Taylor "Some Versions of Difference: Discourses of Hybridity in Transnational Music," in Global Currents: Media and Technology Now, ed. by Oren Tasha G. and Petro Patrice (New Brunswick: Rutgers University Press, 2004), 219-244. 
mixed musical elements. Antoine Busnoys' (1430-1492) Missa L'Homme armé is an example of Renaissance hybridity due to its reconstruction and imitation by several composers including Guillaume Du Fay (1397-1474), Johannes Ockeghem (1410-1497) and Josquin des Prez $(1450 / 55-1521) \cdot{ }^{11}$

Examples of hybridity in music continued in the Baroque period dating from around 1600-1730s with composers such as Johann Sebastian Bach (1685-1750). His interest in music by Italian and French composers allowed him to draw influences and musical idioms from their music into his own compositional language. His French dance suites (BWV 812-817) and his Italian Concerto (BWV 971) demonstrate his combination of different European styles which he reconstructed in his own manner. ${ }^{12}$ Also, in the last variation of the Goldberg Variations (1741), Bach combined two Germanic folksongs: "ich bin so lang nicht bei dir g'west" and "Kraut und Rüben." ${ }^{13}$ The mixture of these two distinct precomposed melodies can also be recognized as blurring the boundary between folk and "serious" music.

The geopolitics and the transgression of national borders further blurred the lines of both physical and musical boundaries during the late seventeenth and early eighteenth centuries, specifically in central Europe. The Treaty of Karlowitz (1699) between Austria and the Ottoman Empire brought not only new territories to central Europe, but also an exposure to Turkish music through the Janissary band. This had a prominent influence on the compositional styles of many

${ }^{11}$ Rob C. Wegman, "Another 'Imitation' of Busnoys's 'Missa L'Homme armé- And Some Observations of 'Imitatio' In Renaissance Music," Journal of the Royal Musical Association 114, no. 2 (1989): 189.

12 Thomas Braatz, "Bach \& Other Influences: Part 2," in Bach Cantatas Website, last modified January 2005, http://www.bach-cantatas.com/Other/Influence-2.htm.

${ }^{13}$ Ibid. 
Western classical composers. ${ }^{14}$ For example, Wolfgang Amadeus Mozart (1756-1791) borrowed the lively tempo and march-like styles of Turkish music in several of his compositions, most notably in the third movement of his Piano Sonata in A Major, K.331 (1783), entitled Alla Turca-Allegretto, popularly known as the "Turkish March."15 The piece encompasses many characteristics of Turkish musical styles through the imitation of cymbals and percussive instruments in the repeated notes, ornaments, and shifts of dynamics. ${ }^{16}$ Many of Mozart's contemporaries also borrowed from Turkish styles including Joseph Haydn (1732-1809) and Ludwig van Beethoven (1770-1827). As advancement in mobility and cultural exchanges grew during the nineteenth century, Nationalism led to increased interest in folk and literary influences during the Romantic movement, and an interest in the "exotic" other. ${ }^{17}$

During the nineteenth century, many composers used folk music as a means of borrowing authenticity. While this practice had been in use for many years (as in the Goldberg Variations), the composers of this period took this kind of borrowing to a new height. Examples of this kind of hybridity can be found in Frédéric Chopin's (1810-1849) mazurkas and polonaises, in which he incorporated several nationalistic Polish elements, particularly rhythms. Other examples of nationalist elements of folk are evident in the symphonic works of the Mighty Five Russian Composers: César Cui (1835-1918), Modest Mussorgsky (1839-1881), Nikolai RimskyKorsakov (1844-1908), Mily Balakirev (1837-1910), and Alexander Borodin (1833-1887). ${ }^{18}$ Among these composers, Rimsky-Korsakov stands out. In his Russian Easter Festival Overture,

\footnotetext{
${ }^{14}$ Eve R. Meyer, “Turquerie and Eighteenth-Century Music,” Eighteenth-Century Studies 7, no. 4 (1974): 487.

${ }^{15}$ Benjamin Perl, "Mozart in Tukey," Cambridge Opera Journal 12, no. 3 (November 2000): 220. ${ }^{16}$ Ibid.

17 A.L. Ringer, "On the Questions of "Exoticism" in $19^{\text {th }}$ Century Music," Studia Musicologica Academiae Scientiarum Hungaricae 7, no. 1/4 (1965): 120.

${ }^{18}$ Edward Garden, "Five, the," Grove Music Online (2001): 1.
} 
he clearly combines music from the Russian Orthodox church with Western styles. He also imagines Eastern styles by depicting distant cultures in his orchestral work, Scheherazade (1888) based on the Middle Eastern folk-tale Arabian Nights. Further examples of hybridity in music in the nineteenth century include an increased interest in the setting of poetry to art music. One of the most prominent composers of lieder was Franz Schubert (1797-1828) who was influenced by the text of poets including Johann Wolfgang von Goethe (1749-1832), Friedrich Schiller (17591805), Matthias Claudius (1740-1815), and Friedrich von Matthisson (1761-1831). ${ }^{19}$ Schubert's Die Schöne Müllerin (1823) and Winterreise (1827) song cycles illustrate Schubert's inclusion of both folk-like and ballad styles as integral elements.

The blurring of distinct nationalistic boundaries expanded drastically at the fin de siècle and well into the twenty-first century. The increased use of folk, popular music, and nonWestern music evolved into musical exoticism, particularly when describing the world outside Western Europe. Examples of this trend include Claude Debussy's (1862-1918) fascination with the gamelan, George Gershwin's (1898-1937) admiration for American jazz, and Béla Bartók’s (1881-1945) collection and incorporation of folk music. Another was Igor Stravinsky (18821971), who displayed hybridity in his use of folk music to evoke Exoticism in his ballets Firebird (1910), Petrushka (1910-1911), and The Rite of Spring (1913). ${ }^{20}$ In the United States, American composer Charles Ives' (1874-1954) use of hybridity is evident in his use of quotation and paraphrasing of American folk tunes, particularly in the work Three Places in New England $(1903-1929){ }^{21}$

\footnotetext{
${ }^{19}$ Maurice J.E. Brown, Eric Sams, and Robert Winter, "Schubert, Franz," Grove Music Online (2001).

${ }^{20}$ Stephen Walsh, "Stravinsky, Igor," Grove Music Online (2001).

${ }^{21}$ J. Peter Burkholder, James B. Sinclair, and Gayle Sherwood Magee, "Ives, Charles," Grove Music Online (October 16, 2013).
} 
The boundaries between musical genres and styles continued to become blurred and indistinct in the twenty-first century as the advancement in technology and media led to a fast and widespread dissemination of information. ${ }^{22}$ During this time, the emergence of contemporary styles such as polystylism and minimalism demonstrated further incorporation of hybridity by composers. Examples of polystylism include Alfred Schnittke's (1934-1998) Concerto Grosso No. 1 (1977) which juxtaposed and quoted works from Antonio Vivaldi (16781741), Wolfgang Amadeus Mozart (1756-1791), and Ludwig van Beethoven (1770-1827). ${ }^{23}$ The influence of non-Western cultures is illustrated by minimalist composers such as Terry Riley (b.1935) and his Sun Rings (2002), which draws upon ideas and elements found in Eastern philosophies and spiritualities. ${ }^{24}$ Similarly, John Cage's (1912-1992) Music of Changes (1951) is influenced by the ancient Chinese I Ching from Asian Zen Buddhist philosophy. ${ }^{25}$

Today, we live in an age of sampling, mashups, remakes, reruns, and a pluralism of genres and styles in popular music. From the Beatles' Sgt. Pepper's Lonely Hearts Club Band (1967) that explores hybridity as it relates to popular music and traditional concert pieces, to Lil Nas X (b.1999) and Billy Ray Cyrus's (b.1961) Old Town Road (2018) that combines rock and roll, country, and rap, hybridity in music has resulted in a pluralistic co-existence of these popular genres and styles. As the scope of this investigation widens, it is essential to examine the influences of hybridity in contemporary flute literature.

${ }^{22}$ Colin Lawson and Robin Stowell, "The Future?", in The Cambridge History of Musical Performance, ed. Colin Lawson and Robin Stowell (Cambridge: Cambridge University Press, 2012), 817.

${ }^{23}$ Joseph Auner, "The Past in the Present," in Music in the Twentieth and Twenty-Frist Centuries (New York: W.W. Norton and Company, 2013), 259.

${ }^{24}$ Terry Riley, Willie Williams, and Blake Marie Bullock, "Sun Rings (2002)," Kronos Quartet, October 22, 2018, https://kronosquartet.org/projects/detail/sun_rings.

${ }_{25}$ James Pritchett, Laura Kuhn, and Charles Hiroshi Garrett, "Cage, John," Grove Music Online (July 10, 2012). 


\section{EXAMPLES OF HYBRIDITY IN SELECTED CONTEMPORARY FLUTE LITERATURE FROM 1970 TO THE PRESENT}

Over the last few decades, hybridity has been a defining characteristic of modern flute literature. Many pieces demonstrate an influence of popular styles such as Mike Mower's (b.1958) Sonata Latino (1994) and Opus di Jazz (1997) which draw upon the musical styles of different Latin American countries and stylistic forms of jazz music respectively. Both pieces are complements of each other and incorporate three movement structures where each movement is named after a particular style or genre. TRKs (2005) and Zoom Tube (1999) by Ian Clarke (b. 1964) both incorporate elements found commonly in Rock and Roll. Clarke describes TRKs as "Pink Floyd for flute" with its electronics and flicks using trill keys. ${ }^{26}$ Similarly, Zoom Tube is influenced by rhythm \& blues and jazz elements which is evident in its experimental and quasiimprovisatory style.

Non-Western influences are also found in many pieces from contemporary flute literature. Toru Takemitsu (1930-1996) incorporated both Western contemporary and Japanese traditional music to establish a language of his own by "exemplifying the coexistence of assimilation and individuality." ${ }^{27}$ Examples include his work Voice (1971), which combines elements of traditional Japanese theatre with lines from a poem by Shuzo Takiguchi (b.1979) and Itinerant (1989), which juxtaposes Western music with an imitation of Japanese shakuhachi

\footnotetext{
26 “TRKs," on Ian Clarke's official website, accessed October 22, 2019, http://ianclarke.net/page22.html.

${ }^{27}$ Noriko Ohtake, "Creative Sources for the Music of Toru Takemitsu," (DMA Diss., University of Maryland, 1990), 1.
} 
flute. ${ }^{28}$ Elizabeth Brown's (b.1953) Trillium (2000) is also heavily influenced by Japanese shakuhachi music and birdsong through its unusual usage of timbres and trills. ${ }^{29}$

In addition to seeking hybridity through novelty and innovation, contemporary flute repertoire often borrows from music of the past. John Corigliano's (b.1938) The Pied Piper Fantasy (1982) demonstrates both borrowing from what came before and the use of theatrical elements through taking inspiration from traditional tin whistle music and incorporating dramatic theatrical elements which require the performer to be an actor, specifically in the last movement where they lead a group of children as they march on and off stage.$^{30}$ Another flute work that incorporates a hybrid of the old and new is George Crumb's (b. 1929) Vox Balaenae (1971). The opening "Vocalise" incorporates the contemporary technique of singing and playing to overtly reference the singing of humpback whales and concludes with a parody quotation from Richard Strauss' (1864-1949) Also Sprach Zarathustra (1896). ${ }^{31}$

\section{SUMMARY}

Although acknowledging some ethnomusicology scholarship which frames musical hybridity as playing into a globalization discourse that extends European hegemony, this document approaches hybridity as a meditative act by the composer in using influential sources and material to inform their compositions. Along with defining the musical "otherness," hybridity in music can also be formed by the mixture of these influential elements to form

\footnotetext{
${ }^{28}$ Elizabeth Robinson, “'Voice', 'Itinerant', and 'Air': A performance and analytical guide to the solo flute works of Toru Takemitsu," (DMA Diss., Ball State University, 2011), 6.

29 "Trillium," on Elizabeth Brown's official website, accessed October 22, 2019, http://elizabethbrowncomposer.com/music/trillium/.

30 "Pied Piper Fantasy (1982)," on John Corigliano's official website, accessed October 22, 2019, http://www.johncorigliano.com/index.php/index.php?p=item2\&sub=cat\&item=29.

${ }^{31}$ Jessica Geels, "Tools for Storytelling: Exploring the Compositional Techniques Crumb Employs in "Vox Balaenae"," (DMA Diss., California State University, Long Beach, 2015), 7.
} 
compositional processes such as musical mixing, merging, melting, influences, and borrowing. Musical hybridity provides a wealth of tools that expand the expressive nuances of musical language such as literary text, the aesthetics of nostalgia, cultural unity, and innovation, along with other "programmatic purposes" (as seen in George Crumb's Vox Balaenae, for instance). Performing a piece of contemporary work requires more than an individual interpretation; it also requires an understanding of the composer's intention within the work. To fully immerse oneself into a piece requires in-depth understanding of the composition, but also knowledge of the different sources of musical influences to form an analytical framework for understanding the pieces. As understanding these influential aesthetics can help to produce a well-informed interpretation of a work, the next chapter explores Coleman's intuitive and inspiration-based compositional process. It will also provide contextual information and a framework that is used later in the text to perform a hermeneutic analysis to explore hybridity within Coleman's Fanmi Imèn and Wish Sonatine. 


\section{CHAPTER 3}

\section{HYBRIDITY IN THE COMPOSITIONAL APPROACH OF VALERIE COLEMAN}

If you are not seeing what you want to see in classical music on the stage or writing the music, be that person. Find those other people with the same minds and push the boundaries. $^{1}$

Jeff Scott

Coleman's compositional style is described by music critics as one that "weaves inspired tapestries of urban-classical roots: living mosaics that connect...culture and humanity."2 Her compositions demonstrate a distinctive adeptness when it comes to merging music with the humanistic experiences of cultures, places, expressions, and social relevance to create a compelling musical storytelling. In an interview with Monica Ellis, bassoonist of Imani Winds, Ellis remarks that Coleman "is just so brilliant at finding sounds of this culture - of our culture here in the United States and the hybridization of that."3 This chapter delves into Coleman's use of hybridity in regards to her compositional process by examining the different sources and materials from which she draws inspiration.

\section{THE COMPOSITIONAL STYLE OF VALERIE COLEMAN}

When asked about her compositional process in a personal interview, Coleman replied,

Since my work is intuition and inspiration based, it always has the investment of conscious and unconscious vulnerability that comes from achieving a state of flow, which is why headspace is critical to the process. Each work always carries either or both joy and sorrow

\footnotetext{
1 Rebecca Julie, "Imani Winds Champions Diversity of Repertoire and Race," The Chicago Maroon, January 23, 2017, https:/www.chicagomaroon.com/article/2017/1/24/imani-windschampions-diversity-repertoire-race/.

2 "Works," on Valerie Coleman's official website, accessed October 13, 2019, https://www.vcolemanmusic.com/works.html.

${ }^{3}$ Monica Ellis, interview with Brittany Trotter, October 29, 2019.
} 
from a personal perspective, as well as either memories or "visualization" of what the premiere performance would look like. ${ }^{4}$

In this quote, Coleman eloquently details the essential traits of her compositions: inspiration and intuition. Coleman finds inspiration in different places, from a poem, a painting, or even a biography of someone who she finds has done something truly unique and great in their lives. These influential elements are the embodiment of her self-described compositional goal of creating a common human experience by drawing upon her experiences of living in an urban setting, relevant subject matters, and literary works. Coleman summarizes her intentions in an interview with the Flute New Music Consortium stating,

The human experience I think is something that is very important to the reason that I write. I also see writing as a means to creating unity-creating love. It sounds cheesy but the creative process is a very positive force within itself. I know this from performing with the likes of people like Wayne Shorter that when there is love on the stage, it just radiates out. It has the potential to change lives. It has the potential to create a sense of well-being in a person. It is almost therapeutic. I look at my music in that very way. I do not write for myself. I never have. It is all about sharing the experience to make people around me better for it. Of course, there is this side benefit of being in the zone of writing and feeling like you are connecting with something that is greater than oneself. You get a taste of that and of course you crave that feeling of touching the divine in a lot of way. ${ }^{5}$

The human experience is a prominent theme in Coleman's compositions and is exhibited through her urban-classical style. Ellis remarks that the concept of "urban-classical" was an idea that Coleman and Jeff Scott, hornist and resident composer of Imani Winds, had in describing the influences of the grit of urban and city life on their music. As a native of Louisville, KY, Coleman's proud Louisvillian identity can be heard in her works. Ellis explains that "growing up, she would hear sounds, the vernacular, and the soulfulness in the people. It is very clear in

${ }^{4}$ Valerie Coleman, interview with Brittany Trotter, November 24, 2019.

${ }^{5}$ Valerie Coleman, "FNMC Presents: Interview with Valerie Coleman," interview by Karen Large, Flute New Music Consortium, video, 18:59, November 17, 2018, https://www.youtube.com/watch?v=t-ZUu86SP-8. 
her music and you need to know this to understand the sensibility in her music." ${ }^{96}$ Themes of urban sprawl and landscapes are evident in Coleman's Rubisphere (2015) series works for chamber trios. Written for flute, clarinet, and bassoon, Rubisphere \#1-4 contain virtuosic and lyrical movements that portray the grunge and grooves of living in a New York City neighborhood such as the Lower East Side or Washington Heights. Rubisphere also demonstrates another source of inspiration for Coleman: her young daughter Lisa. She states, "Lisa allows me to become much more efficient and strategic with my writing time. Watching her grow, and that kind of energy, informs the way I phrase music and charges me in such a way that really inspires me to write." ${ }^{7}$ In remarking how motherhood influences Coleman's compositional writing, Ellis refers in particular to the second movement of Rubisphere, stating,

In regards to how being a mother influenced her work, I can think of one piece that she wrote for wind trio (flute bassoon and clarinet). It's a three-movement work. She wrote the works slightly separate from one another in time and then decided to combine them into a suite. The middle movement was written after Lisa was born. It's a beautiful lullaby that is sandwich in-between these two power house type pieces. It is a beautiful contrast to the other two movements, but that would have never happened unless she had her daughter. Just the sounds she had in her head was related to being a mom. ${ }^{8}$

Along with motherhood and big city life, Coleman writes compositions that also trace back to her southern country roots. In Red Clay and Mississippi Delta (2009) for wind quintet, Coleman uses an array of melodies, harmonies, and rhythms characteristic to popular bluesy juke box tunes to portray images of river casino boats traveling down the Mississippi River. The title also presents a double entendre referring both to the cultural Red Clay Hills region and also the

\footnotetext{
${ }^{6}$ Ellis, interview with Trotter.

7 "Women's History Month Spotlight: Valerie Coleman," University of Miami News, March 7, 2019, https://news.miami.edu/frost/stories/2019/03/valerie-coleman-womens-month.html.

${ }^{8}$ Ellis, interview with Trotter.
} 
skin tone of Coleman's relative from the area who was described as having "dark skin that looks like it came directly from the red clay."

Coleman's compositional style also demonstrates a strong sense of consciousness and sensitivity to societal changes. In describing this consciousness, Coleman states, "The one thing that composers can do which makes us very dangerous is we record the times and create new histories, by basically interpreting what has happened onto the music, onto the page."10 Throughout her career, Coleman has used what is going on around her as a way to inform her music. Ellis elaborates on Coleman's conscious writing stating,

She is writing music that has this incredible social conscious platform to it, but not because she has to be socially conscious. You know, she is inspired by that and really fired up by things. It is innate, it is organic, it is not something that is for a reason... but I do not think her music is reactionary as much as it is inspired by life. She is just this extraordinary talented person who has a lot to say. Her music is not for music sake, and I think as a really sensitive musician and artist we all have to be. We are naturally influenced by the world around us in a constant. Sometimes pieces do just come out that will be a reaction to a particular event or a history. I think that the composers who are sustainable are the one that are constant making music that you feel that need to be made regardless of what is happening in the world. ${ }^{11}$

Coleman's sensitivity to cultural relevance is demonstrated in several of her most recent works. She incorporates this by interpolating musical motifs inspired by current events with the words of historical figures and poets. For instance, Coleman's Phenomenal Women (2018) for wind quintet and orchestra depicts a celebration of women's efforts to overcome adversity

\footnotetext{
9 "Red Clay \& Mississippi Delta for Wind Quintet," on Valerie Coleman's official website, accessed October 18, 2019, https://www.vcolemanmusic.com/store/p1/Red_Clay_\%26_Mississippi_Delta_for_Wind_Quinte t_\%28Digital_Download\%29.html.

${ }^{10}$ Annie Holmes, "Hear it at the Library: The Orpheus Chamber Orchestra Performs a New Work Inspired by Maya Angelou's "Phenomenal Woman"," Library of Congress, May 20, 2019, https://blogs.loc.gov/catbird/2019/05/hear-it-at-the-library-the-orpheus-chamber-orchestraperforms-a-new-work-inspired-by-maya-angelous-phenomenal-woman/.

${ }^{11}$ Ellis, interview with Trotter.
} 
through a musical portrait of prominent women including Maya Angelou, Katherine Johnson, Serena Williams, Michelle Obama, and Claressa Shields. Inspired by Maya Angelou's poem and book of the same name, the piece presents a movement dedicated to the immigrant women of the 2018 Central American migrant caravan traveling to the U.S southern border "only to be separated from their children." 12 In A Right to Be (2017) for flute, clarinet, bassoon, and piano, Coleman highlights the immigrants again as a response to the uncertain future of Dreamers and the "unwelcoming of immigrants from what was referred to as undesirable countries." 13 The rebuilding of New Orleans during the aftermath of Hurricane Katrina in August 2005 is the premise of Coleman's Pontchartrain (2011) for flute choir. When asked in an interview by the podcast Flute Unscripted about the cultural and current themes of the work and its place amongst the classical Western cannon, Coleman responds,

There is a faction of the old guard that will always adhere to the Beethoven cycles, string quartets, and other traditionalist venues, and that should always be. I am a firm believer in celebrating what have has come before. The way things are going on in the world right now is something that makes me jump out of my skin in frustration and worry. And just being a mom as well makes me think of the world I am raising my daughter in. And so, when you see all these things happening around you as an artist, it is a different kind of fuel. I always look at New York City and I love it so much because its charges me in a beautiful way. And it is not just for me, but it is for artists all around. And when artists in mass start to write about different topics that address humanity, that address morality, that address the darkest to the lightest nature of things, that creates a way that basically presenters have no choice but to follow that. Because what nourishes the artists will nourish the audience as well. ${ }^{14}$

\footnotetext{
12 Brad S Ross, “American Composers Orchestra at Zankel Hall,” Oberon's Grove, November 7, 2018, https://oberon481.typepad.com/oberons_grove/2018/11/american-composers-orchestrazankel-hall.html.

13 Valerie Coleman, "A Right to Be for Flute, Clarinet, Bassoon and Piano (2017)," Chamber Music Northwest, accessed October 13, 2019, https://cmnw.org/music/valerie-coleman/.

${ }^{14}$ Caity Massoud, "Valerie Coleman," January 15, 2019, in Flute Unscripted, podcast, MP3 audio, 30:55, https://player.fm/series/flute-unscripted/valerie-coleman.
} 
The literary works of renowned cultural authors and poets have been in the forefront of influential sources for Coleman's compositions. In Portraits of Langston (2007), Coleman interweaves selected poems of Langston Hughes as something of a call and response between narration and music. speech. and canzone (2002), Coleman's first work with electronics, digitally manipulates the speech Robert Kennedy delivered in New York announcing the assassination of Martin Luther King, Jr. along with speeches by social justice and human rights advocates A. Phillip Randolph and Cesar Chavez. She accompanies those quotations with music for wind quintet and electronics. Along with blending literary works in her composition, Coleman highlights prominent African-American people and culture in her work referencing Josephine Baker in Suite: Portraits of Josephine Baker (2006) and Muhammad Ali in Shotgun Houses (2018).

What primarily makes Valerie Coleman relevant in terms of hybridity is her intentional incorporation of popular American music elements of blues, jazz, and gospel (her Louisvillian identity) with modern classical styles. ${ }^{15}$ Ellis remarks, "She is a proud Louisvillian. Growing up, she would hear sounds, the vernacular, and the soulfulness in the people. It is very clear in her music and you need to know this to understand the sensibility in her music."16

This fusion between Western classical and Americana music represents another derivation of both Coleman's "urban-classical" compositional style and her conceptual theme of unity within diverse cultures. It is not hard to find Coleman's nods to transculturalism in her works such as her Afro-Cuban Concerto (2011), Umoja (2001), and Tzigane (2011). For example, Coleman's Tzigane for wind quintet draws upon influences from eastern European

\footnotetext{
${ }^{15}$ Louisvillian refers to a native of Louisville, KY.

${ }^{16}$ Ellis, interview with Trotter.
} 
cultures and her experience collaborating with Palestinian oud player Simon Shaheen. The piece encompasses rich traditional elements of "gypsy" music within a contemporary idiomatic

Western compositional style. In addition to incorporating musical styles and genres from America, Africa, and Europe, Coleman uses musical elements originating from Latin America. Examples include her solo flute work Danza de la Mariposa (2008), which is a musical homage to rhythmic elements of South American music, which in turn represent a dancing South American butterfly.

Inspiration from creative individuals also imbues Coleman's compositional process. Although she does not interject structured improvisation in her compositions, she does encourage the performer to interpret the work using their own personal connections that lend the performance depth. In her program notes, she writes specific instructions for the performer to "lightly relax standard classical phrasing, in favor of an organic interpretation," and "embrace the cultural "nods" through their interpretations."17

As a flutist-composer, Coleman brings her intimate knowledge and skills of the flute into her writing process stating,

As I have gotten older, I have started to pick up the flute more and more and use it as a means of creating melodies and harmonies I think that has a lot to do with the practice of improvising. It's something that twentieth-first century music is starting to embrace more and more. However, I find that when you improvise, you increase your musical language; you increase your own musical style; you increase your own particular voice and then it's a matter of documenting that." 18

17 Valerie Coleman, Wish Sonatine, ed. by Anne Pollack (Malven: Theodore Presser Company, 2015), 2; Valerie Coleman, "Fanmi Imèn," Valerie Coleman. (Malven: Theodore Presser Company, 2018), 1.

${ }^{18}$ Heidi Kay Begay, "An Interview with Valerie Coleman," December 8, 2018, in Flute 360, episode 37, podcast, 40:33, http://heidikaybegay.libsyn.com/episode-37-an-interview-withvalerie-coleman. 
Coleman's flute works display a defining element of virtuosity in the same manner as her flutistcomposer predecessors and contemporaries. When asked what she likes and what she finds challenging in writing for flute, she states

I think it is equal in what I like and what I found challenging, because the challenge is finding those melodies, finding those rhythms, finding those elements that lead into the rest of the work itself. They are the seeds that you know that are going to grow deciphering which one you are going to use in the moment, or which one that are going to be used in a piece. ${ }^{19}$

Coleman's compositions for flute are highly motivic in nature partly due to the intuitive way that she thinks of melodic ideas. In explaining her process for her work Fanmi Imèn (2018), Coleman remarks,

A lot of motifs came to the foreground, but I could not really commit to any one of them. It really is a decision-making process. However, something inflammatory happened in the news that allowed me to get mad enough to choose a melody. From there, that anger turned into love once the melodies started to manifest itself and grow, and become this building block for other thematic material to happen. So, all the materials that came before that was chunked out the window. You know, that is a hard pill to take when you work weeks upon weeks on material that is just not going to happen. But then, as I was writing that piece, another piece came into my mind from that discarded material. Within a span of several months, two pieces came out. You never know what is going to happen. I think that is the challenge of it and it takes a lot of faith to know that a work will find itself. A work will develop itself, and it does not necessarily develop within the time frame that you want it to... I always maintain that pieces are their own living entity. They do not breath, they do not eat, but yet the impact that they make upon others makes them beings onto themselves. ${ }^{20}$

A thorough examination of the musical motifs in Coleman's works is key to

understanding the hybridity she presents in her works. The following section provides a both a formal/motivic analysis and something of a hermeneutic analysis of Coleman's Wish Sonatine and Fanmi Imèn for flute and piano. Both works are presented in the form of tone poems which

${ }^{19}$ Valerie Coleman, "FNMC Presents: Interview with Valerie Coleman," interview by Karen Large.

${ }^{20}$ Ibid. 
incorporate motifs that represent literary and musical imagery. The analyses serve to clarify Coleman's intentions and provide valuable insights in interpreting her music.

As previously stated, performing a piece of contemporary work requires more than an individual interpretation; it also requires an understanding of the composer's voice and influences that shape their work. In reference to the musicians performing Coleman's works, Ellis remarks, "Like don't play her music without knowing something about her. Because you will miss something for one. Even if you do not have that experience, knowing the experiences of the composer, of her specifically, and that identity will really inform you to how to play it. It will be a more enjoyable experience for the performer knowing her identity."21

${ }^{21}$ Ibid. 


\section{CHAPTER 4}

\section{A HERMENEUTIC ANALYSIS OF WISH SONATINE \& FANMI IMÈN}

This chapter is an exploration of Coleman's use of hybridity and cultural influences in Wish Sonatine and Fanmi Imèn for flute and piano. The hermeneutic analysis serves to provide contextual insight into the musical narration of the poem as represented through both the use of traditional characteristics of non-Western melodies, harmonies, and rhythms, and through the use of melodic motifs and other influential materials and sources. As such, this analysis could provide valuable insight to performers who wish to interpret the works while also providing examples of musical hybridity.

\section{BACKGROUND OF WISH SONATINE FOR FLUTE AND PIANO}

Wish Sonatine is Coleman's first composition for flute and piano. The piece was commissioned in 2015 by the Virginia Polytechnic Institute and State University with support from flutist Elizabeth Crone and pianist Dr. Richard Masters and was sponsored by a grant from the Diversity Committee of the Virginia Tech College of Liberal Arts and Human Sciences. In an interview with the Flute New Music Consortium, Coleman reflected upon the experience of composing Wish Sonatine. She remarks,

This piece was an eye opener, knowing that I was writing for another flutist and she [Elizabeth Crone] already had the subject material in mind. There is a professor at Virginia Tech who is a poet. He wrote about the Middle Passage. And when she [Elizabeth Crone] came to me about that, I was utterly fascinated. Of course, I was a little bit hesitant because being an African-American composer, there is this stigma that African American composers only write about their experience, their culture, their heritage. And I was really done with that particular concept, because surely there is much more to all of us as creators. But at the same time, it really made me take a hard look at what's my responsibility is as a composer, to not only record the times, but to present history in a way that can be received with openness. Music heals, it informs, and its bridges gaps between differences of opinion, so I took it on and that allowed me to really dive into that history of the Middle Passage, and there was so much I did not know. And I am so grateful for Elizabeth introducing me 
to that piece. So, I think by far that is my favorite flute composition that I have written to date. $^{1}$

As stated in the program notes provided by Coleman, Wish Sonatine "is based upon a historical journey called the Middle Passage: the selling, trading, and transporting of enslaved Africans from Africa to the New World, as referenced in the poem of the same title by Fred D’Aguiar."2 Fred D’Aguiar is a British-Guyanese poet, novelist, playwright, and Professor of English at the University of California, Los Angeles. "Wish," is among a collection of poems from D’Aguiar published book entitled The Rose of Toulouse, which depicts the places D'Aguiar has lived, their stories, and his personal history developed through his travels. In "Wish," Fred D'Aguiar presents a narration of the experiences of his African ancestors, describing his desire for the European merchant ships to have brought goods and materials to be shared and traded with the natural resources of Africa, instead of trafficking millions of native Africans across the Atlantic Ocean. D'Aguiar's uses of imagery includes recreating the bell toll sounds of the slave ship and the crackling of whips and chains, which creates a tone of reflection upon one of the greatest tragedies in world history. In the score, Coleman explicitly recommends for the poem to be recited prior to the performance to provide context to the listener. "Wish" presents themes of hybridity, identities, and heritages that fit well with Coleman's own stylistic traits of blending diverse musical styles and genres.

\footnotetext{
${ }^{1}$ Valerie Coleman, "FNMC Presents: Interview with Valerie Coleman," interview by Karen Large, Flute New Music Consortium, video, 18:59, November 17, 2018, https://www.youtube.com/watch?v=t-ZUu86SP-8.

${ }^{2}$ Valerie Coleman, Wish Sonatine, ed. by Anne Pollack (Malven: Theodore Presser Company, 2015), 2.
} 


\section{ANALYSIS OF WISH SONATINE FOR FLUTE AND PIANO}

Wish Sonatine demonstrates several stylistic characteristics of French twentieth and twenty-first century flute sonatines by composers such as Henri Dutilleux and Pierre Sancan by demanding that the performer execute with a high level of technique and skillful musical interpretation. The incorporation of blues and jazz idioms, rhythmic traits of the African djembe drum, and contemporary techniques such as flutter tongue, percussive sounds, and tone clusters demonstrates Coleman's style of hybridizing Western common tonal practices with musical influences from her African-American heritage as a foreground for musical exploration. An understanding of Coleman's use of hybridity of music and text can guide performers of Wish Sonatine towards an interpretation that balances African/African-American influences with modern Western art music.

Wish Sonatine is significant among Coleman's flute works due to it being her first work composed solely for flute and piano. The piece requires the performer to create timbral imagery of the visceral scenes of the Middle Passage as depicted by D'Aguiar's "Wish", often requiring the player to "lightly relax standard classical phrasings, in favor of an organic interpretation."3 It is also full of rhythmic complexity and includes several extended flute techniques, as well as giving the performer opportunities to explore diverse timbres. In terms of its musical material, Wish Sonatine is a cogent and unified single movement tone poem structured with five discernable sections consisting of developed themes and motifs throughout. Since the historical reference to the Middle Passage and D'Aguiar's poem are an integral component of the piece, I will provide snippets of Coleman's program descriptions to provide justification for applying concepts of musical hybridity to the selected musical examples.

\footnotetext{
${ }^{3}$ Coleman, Wish Sonatine, 2.
} 
Wish

I wish those tall ships at Africa's shore

Had dropped anchor to plant crops there:

Sugarcane, tobacco, cotton and coffee.

Instead they filled the hungry bellies

Of hulls with Africans and set sail

Wanting nothing from that big place

That wasn't diamond, gold, ivory, flesh.

I wind the clocks back and turn the ships

Around, not a single bullet, whip, or cutlass

Sound to deafen our ears for centuries.

No Atlantic road of bones from people

Dumped into the sea to form a wake.

Figure 4.1. "Wish" from The Rose of Toulouse by Fred D'Aguiar, copyright (c) 2013 by Fred D'Aguiar. Used by permission of Carcanet Press Limited. All rights reserved.

The structure of Wish Sonatine can be divided into five sections. Using the measure numbers as well as Coleman's descriptions as markers, the sections are as follows:

\begin{tabular}{|c|c|c|c|}
\hline Measures & $\begin{array}{l}\text { Form \& Themes } \\
\text { Zones }\end{array}$ & Stylistic Sections & $\begin{array}{l}\text { Programmatic } \\
\text { Description }\end{array}$ \\
\hline $\begin{array}{l}\text { mm. 1- } \\
172\end{array}$ & $\begin{array}{l}\text { Exposition } \\
\text { C Minor } \\
\text { Introduction Theme } \\
\text { mm.1-26 } \\
\text { mm.57-107 } \\
\text { Primary Theme } \\
\text { mm.35-56 } \\
\text { Secondary Theme } \\
\text { mm.107-172 }\end{array}$ & $\begin{array}{l}\text { Placid, then soulful }(d=72) \\
\text { With fighting desperation, } \\
\text { Cadenza rubato con molto } \\
\text { agitato }(d=96-104) \\
\text { Passionate (half note }=84-88 \text { ) } \\
\text { Movendo (half note }=84) \\
\text { Poco a poco pui con fuoco } \\
\text { Vivo }(d=172) \\
\text { A tempo }(d=172)\end{array}$ & $\begin{array}{l}\text { Visions of tall ships. } \\
\text { Slaves being herded onto } \\
\text { the ship. } \\
\text { Whips are cracked and } \\
\text { slaves are dragged, } \\
\text { pushed, and beaten. }\end{array}$ \\
\hline
\end{tabular}




\begin{tabular}{|c|c|c|c|}
\hline $173-223$ & $\begin{array}{l}\text { Development } \\
\text { Third Theme } \\
\text { mm.173-223 }\end{array}$ & $\begin{array}{l}\text { Still }(d=60) \\
\text { Chaotic, gradually more } \\
\text { anxious }(d=80)\end{array}$ & $\begin{array}{l}\text { Slaves resorting to } \\
\text { terminal starvation or } \\
\text { suicidal jumps off the } \\
\text { ship as the very last thing } \\
\text { that could be done to } \\
\text { escape captivity and } \\
\text { claim their personal } \\
\text { sovereignty. } \\
\text { Slavers' attempts to } \\
\text { discourage suicide since } \\
\text { it represented a loss of } \\
\text { profit. } \\
\text { Slave's fierce } \\
\text { determination to reclaim } \\
\text { self-worth. }\end{array}$ \\
\hline $224-286$ & $\begin{array}{r}\text { Recapitulation } \\
\text { Primary Theme } \\
\text { mm.224-232 } \\
\text { Introduction theme } \\
\text { mm.234-254 } \\
\text { Secondary theme } \\
\text { mm.255-286 }\end{array}$ & $\begin{array}{l}\text { With fierce determination to } \\
\text { survive }(d=132) \\
\text { Con molto agitato (half note } \\
=80)\end{array}$ & $\begin{array}{l}\text { Communicates a dual } \\
\text { reflection: 1) A sense of } \\
\text { self-preservation, the } \\
\text { embrace and healing } \\
\text { possibility in a multitude } \\
\text { of cultures brought from } \\
\text { Africa despite captivity } \\
\text { and 2) An echo of } \\
\text { D'Aguiar's poem as it } \\
\text { refers to turning the ships } \\
\text { around and changing } \\
\text { history, thereby avoiding } \\
\text { the sound of the whip. }\end{array}$ \\
\hline $287-302$ & Coda & $\begin{array}{l}\text { Con molto agitato (half note } \\
=80 \text { ) }\end{array}$ & $\begin{array}{l}\text { Reference to the last two } \\
\text { line of the poem. }\end{array}$ \\
\hline
\end{tabular}

Figure 4.2. Form Chart of Wish Sonatine for Flute and Piano

Musically, the piece follows a fairly standard sonata form, however, a more distinctive structure is provided by the thematic material that is derived from the various melodic and rhythmic motifs presented in both the flute and piano. Coleman uses several compositional techniques to unify the entire work. The first technique is the use of motifs to provide a common thread through much of the melodic writing. The second technique, rhythmic ostinato, provides 
moments of tension and release that affect the harmonic material. Finally, the third technique is melodic fragmentation, in which the motives used in some sections seem to emerge from the successive repetition of thematic statements. In addition, Coleman makes use of the voicing of the flute to present traditional sense of lyricism that is commonly seen in French flute music. This singing quality also draws parallels to traditional African music where the voice takes pride of place among other African musical instruments. ${ }^{4}$ Throughout the piece, Coleman uses the voicing of the flute to represent the range of and semiotic association with African voices which are defined by musicologist Kofi Agawu as "exclamation and extreme repression of grief with higher register, pausing or reposing with the middle register, and resignation and despair with low register." 5

\begin{tabular}{|l|l|}
\hline Motif & Musical Example \\
\hline $\begin{array}{l}\text { Cat o'nine tails } \\
\text { whip } \\
\text { (flute) }\end{array}$ & $\begin{array}{l}\text { Moving water } \\
\text { flute) }\end{array}$ \\
\hline $\begin{array}{l}\text { Djembe drum } \\
\text { (flute) }\end{array}$ & \begin{tabular}{l} 
(cadenza) \\
\hline
\end{tabular} \\
\hline
\end{tabular}

${ }^{4}$ Kofi Agawu, The African Imagination In Music (New York: Oxford University Press, 2016), 85. ${ }^{5}$ Ibid., 88. 


\begin{tabular}{|l|l|l|l|l|}
\hline $\begin{array}{l}\text { Coercion and } \\
\text { Resistance } \\
\text { (flute) }\end{array}$ & $\begin{array}{l}\text { Inner } \\
\text { contemplation } \\
\text { (piano) }\end{array}$
\end{tabular}

Figure 4.3. Motif Chart of Wish Sonatine for Flute and Piano ${ }^{6}$ - (C) 2015 by Theodore Presser Company

In discussing the motivic features of the piece with Coleman, she states,

In general, I always try to find a direct music translation/sound to actions, occurrences, or intentions. My writings are heavily intuition-based and simplistic, in which I search for the essence of things (intention and imagery) and how I feel about it, and then, what resonates the most (what feels right). What sometimes results is a musical idea that is often translated by others to have more depth and meaning than what I initially intended. I wish I could lay claim to these motifs having a deeper intellectual layer, but in truth, my goal is to tell the story as simply and descriptively as I can. ${ }^{7}$

The thematic material that serves as an introduction to the piece portrays a distant horn call of a slave ship in the Atlantic. The senza vibrato in the flute allows for the flutist to produce a blaring hollow tone color that is augmented by the piano's sustain pedal to create a distant echoing effect. The melodic fragment of the horn call in the flute is further developed at the beginning of the exposition in measures 14-26, creating a dirge-like melody which leads to a startling shriek by the flute at the end of measure 26. This shriek marks a motivic figure that occurs throughout the piece and is used to represent the crackling of the cat o'nine tails whip (Figure 4.3). ${ }^{8}$ Coleman describes the cat o'nine tails motif as depicted throughout as eighth note

\footnotetext{
${ }^{6}$ The names of the motifs are a mixture of my interpretation and Valerie Coleman's liner notes descriptions.

${ }^{7}$ Valerie Coleman, interview with Brittany Trotter, November 24, 2019.

${ }^{8}$ The cat o'nine tails is a whip with nine knotted lashes made out of leather, ivory and rope. This whip was used during the transatlantic slave trade by sailors to punish African captives on board ship.
} 
high B's and other quick shrieking leaps such as those that occur in mm. 26, 36, 39, and other instances throughout the work. ${ }^{9}$

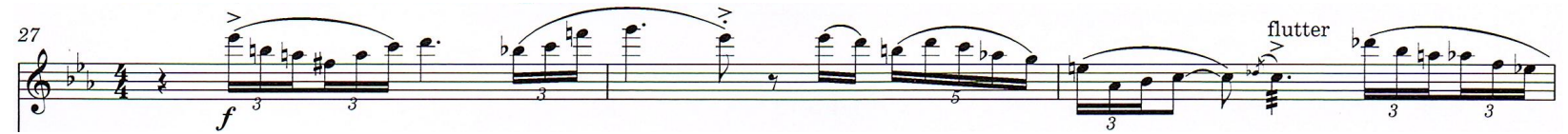

Figure 4.4. Wish Sonatine: $\mathrm{mm}$. 21-29, broken arpeggios in the flute representing herding slaves and the crackling of whips. (C) 2015 by Theodore Presser Company

Along with the cat o'nine tails whip motif, it is my interpretation that the flute cadenza in the next section draws on the tonal imagery of the second stanza of the poem (Figure 4.1). The broken chords and arpeggios shown in Figure 4.4 could be interpreted as slavers herding slaves onto the ships in groups as they shackled male captives in pairs with iron chains, often storing them below-deck while the women and children would be left unbound and separated from the men by a barricado. ${ }^{10}$ The cat o'nine tails whip motif occurs five times with two of those instances using flutter tongue for a more aggressive sound. I interpret the flutter as a physical stinging sensation from the cat o'nine tails whip tearing the skins on the back of the slaves. The flourish of melodic gestures in the flute during the cadenza represents the slaves' desperate but futile fight to stay on their homeland soil. ${ }^{11}$ Starting at the in tempo, the flute presents the primary thematic material which occurs again in the recapitulation in measure 224 . The primary theme material consists of a succession of rhythmically driven sixteenth runs and sforzando flutters. This rhythmic ostinato abruptly stops in measure 39 , followed by another motivic device titled "Middle Passage" involving both the flute and piano. The middle passage motif consists of the flute's sixteenth triplets which leads to a shared pitch D that is accented by both instruments.

\footnotetext{
${ }^{9}$ Coleman, interview with Trotter.

${ }^{10} \mathrm{~A}$ barricado is reinforced wall that could be used to protect crew members in case of a revolt.

${ }^{11}$ Coleman, Wish Sonatine, 2.
} 
Coleman refers to the Middle Passage motif as a main pivot to a transition into the next "vignette" of the story, however, agreed with my proposition that the repeated pitch D represents three distinct bells of the three ports of the triangular trade (Figure 4.5). ${ }^{12}$

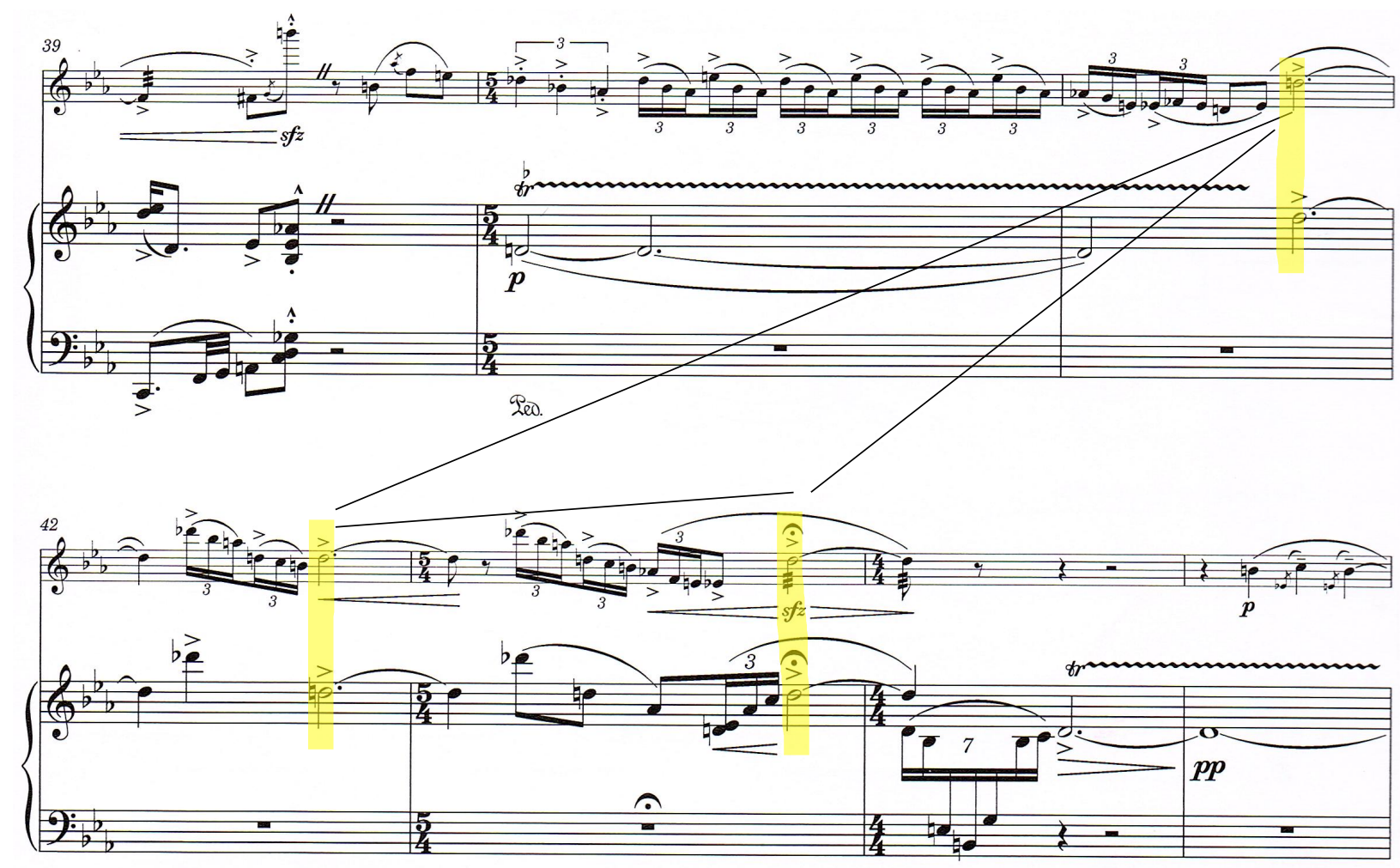

Figure 4.5. Wish Sonatine: mm. 39-45, Middle Passage motif. (C) 2015 by Theodore Presser Company

Representing the pride and culture within the main tribes on board of the ship, the next section, passionate, starts with a rhythmic ostinato in the piano which is maintained throughout the section with slight modifications. ${ }^{13}$ The melodic material presented in the flute further develops the melodic motif of the horn calls from the beginning of the exposition. The Movendo section introduces the secondary theme which is presented first by the piano's moving water

\footnotetext{
${ }^{12}$ Coleman, interview with Trotter.
}

${ }^{13}$ Coleman, Wish Sonatine, 2. 
motif that consists of repeated triplets and is taken over by the flute six measures later, which could be an example of call-and-response. Coleman describes this motif stating,

As the European ship sails off, I want to address the way European composers always depict water movement and mystery (Moldau), but give it a twist that denotes the presence of Africans as cargo. There is also the perspective of the enslaved people, a sense of wonder in not knowing where they are going, but also initial thoughts of trying to find ways off the boat. $^{14}$

The moving water motif can also represent the eighth line of the poem creating a sense of moving on the water and sailing into the unknown (Figure 4.1). ${ }^{15}$

In the Poco più con fuoco, the moving water motif is juxtaposed with a rhythmic African djembe drum-like motif in the flute (Figure 4.3). The djembe drum motif is developed further into a short ad lib cadenza in measures 144-148. Coleman describes imitation of the djembe drum in the flute as, "the more common rhythms of the Djembe drums needed to be used in a way that there was no doubt that the flute IS the djembe." ${ }^{\prime 16}$ This djembe motif could represent the male slaves being forced to "dance" on the deck. ${ }^{17}$ Historically, the slaves" "dance" was normally accompanied by pounding on African drum, such as the djembe, or African banjo. The djembe flute cadenza ends with a fortissimo flutter cat o'nine tails whip motif in measure 148, which leads me to interpret this ending as the punishment for the slaves who refused to "dance." A short transition from measures $150-172$ establishes the modulation to D minor before the start of the development of the piece marked as Defiant.

\footnotetext{
${ }^{14}$ Coleman, interview with Trotter. Moldau is a reference to Bedřich Smetana's The Moldau (1874), a symphonic poem that describes the Moldau river from the mountains to Prague. ${ }^{15}$ Coleman, Wish Sonatine, 2.

${ }^{16}$ Coleman, interview with Trotter.

${ }^{17}$ To ensure a good price for the slaves upon arrival, the captain had to keep the slaves in relatively good physical condition, so to achieve this the slaves were forced to jumped up and down and dance, something which were extremely painful for the men who were still chained together.
} 
The development section is shorter than both the exposition and recapitulation, however, it presents new thematic material creating the most emotionally provoking section within the entire piece. It is during this section that Coleman advises the performer to "relax standard classical phrasing in favor of an organic interpretation." 18 Quasi-improvisatory in fashion, the harmonies subtly hint at Eb major halfway through the section, although it is not until the end of the development that the audience finally receives the satisfactory tonic chord in Eb major. Furthermore, the development section presents two melodic motifs: coercion and resistance and inner contemplation (Figure 4.3). The first motif, coercion and resistance, is presented by the flute in a simple melody that develops within the three repetitions in which it occurs. Coercion and resistance represent the slaves' attempts to claim back their lost freedom. Coleman further explains this motif as "having the flute convey what are reactionary characteristics of a person going through trauma: shrieks of defiance through leaps in and out of the flute's upper register, hard articulations to emulate aggressive behavior." 19 This motif is further developed in mm. 189-192 into the jumping ship motif, referring to the description in the program notes stating, "Trafficked individuals occasionally resorted to terminal starvation or suicidal jumps off the ship as the very last thing that could be done to escape captivity and claim their personal sovereignty." ${ }^{20}$ The inner contemplation motif is presented by the rhythmic quarter-note triplet ostinato in the piano starting in measure 177. Coleman offers another vignette representing the slaves' inner contemplation of suicide by jumping overboard into the ocean from measures 191-192. The most characteristic trait of this passage is the grace-note that accompanies the start of each iteration as shown in Figure 4.6. This type of grace note embellishment is exhibited in

\footnotetext{
${ }^{18}$ Coleman, Wish Sonatine, 2.

${ }^{19}$ Coleman, interview with Trotter.

${ }^{20}$ Coleman, Wish Sonatine, 2.
} 
many traditional African-American spirituals and also gospel music. The passage develops in a quasi-improvisatory fashion while the piano continues its rhythmic motif underneath and builds into a climatic surge an octave higher than when it was originally stated. The high register wails in the flute are reminiscent of African-American gospel choirs singing to the rafters of church, clearing a way to get to the heavens. The reinforcement of the piano on $\mathrm{C}$ provides added characteristics of a full gospel choir with a soprano soloist ringing above. The melody subsides to what Coleman describes as the most passionate moment of Defiant, which occurs in measure 214 as the flute and piano play a single note a major third apart. Coleman remarks, "I envision an enslaved woman experiencing a still moment in time, a profound sweetness of looking onto her newborn after giving birth." 21 This image was preceded by the usage of the flute pitch bend in measure 196 provokes tonal imagery which Coleman refers to as the moan from labor pains as shown in Figure $4.7 .^{22}$

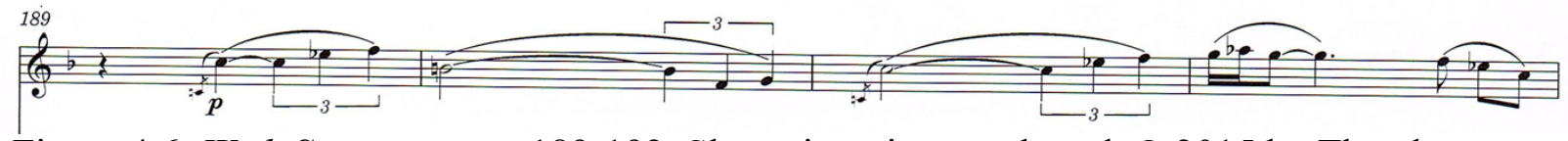

Figure 4.6. Wish Sonatine: mm.189-192, Slaves jumping overboard. (C) 2015 by Theodore Presser Company

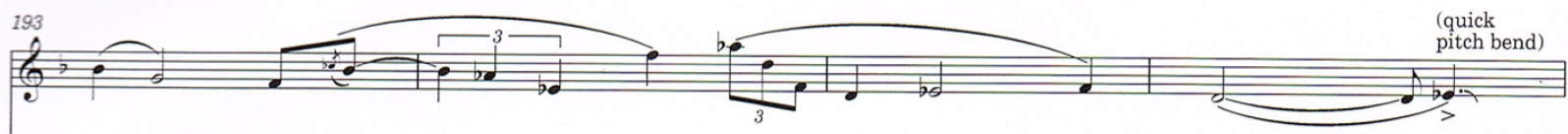

Figure 4.7. Wish Sonatine: mm.193-196, Moan from labor pains. (C) 2015 by Theodore Presser Company

The Still section presents a short transition into the recapitulation representing, "a precursor to African-American spirituals and blues." Chaotic, gradually more anxious, marks a

${ }^{21}$ Coleman, Wish Sonatine, 2.

${ }^{22}$ Coleman, interview with Trotter. 
return to the thematic material that was first seen in the exposition. Starting at measure 224, the flutist plays a slight variant of the primary theme material in the flute with the interjection of the cat o'nine tails and djembe motif. Underneath the flute, Coleman writes a series of sforzando tone clusters in the piano, explicitly asking the pianist for full left forearm contact to produce many white and black keys notes as possible.

The next section, With fierce determination to survive, starts with the quarter triplet ostinato motif that occurred in the Defiance section. The flute presents a tribal-like flourish as a rhythmic variation of the first motif. The re-emergence of the cat o'nine tails whip motif in measure 248 , the moving water motif in measure 260 , and the djembe drum motif in measure 271 represents the first part of the dual reflection in the recapitulation: "a renewed sense of selfpreservation, the embrace and healing possibility in a multitude of cultures brought from Africa despite captivity." 23 A metamorphosis of all the various motifs is presented in the coda from measures 287-302. The inner contemplation motif continues in the right hand of the piano with sporadic interjections of the moving water motif while the left hand relentlessly carries the bluesy bass figuration until the end. Starting with a four-measure repetition of the cat o'nine tails whip motif, the flute presents short jabs of the djembe drum motif before a brief cycle of the moving water motif. The last four measures of the piece presents part two of the dual reflection: “an echo of D'Aguiar's poem as it refers to turning the ships around and changing history, thereby avoiding the sound of the whip "to deafen our ears for centuries." ${ }^{24}$ The final four measures, through the two octave spanning leaps in the flute and the rhythmic stomps of the piano, conveys the poem's last two lines (Figure 4.8).

\footnotetext{
${ }^{23}$ Ibid.

${ }^{24}$ Coleman, Wish Sonatine, 2.
} 


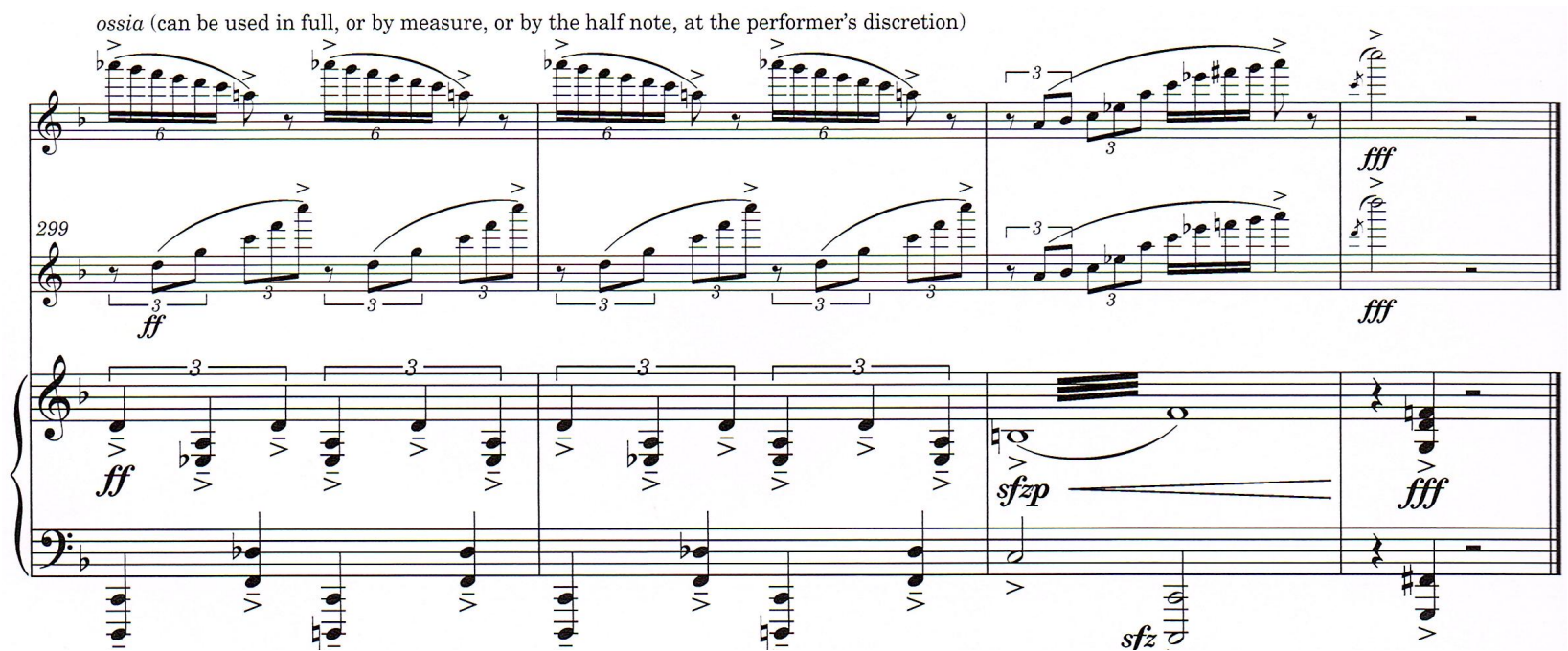

Figure 4.8. Wish Sonatine: $\mathrm{mm}$. 299-302, The flute extreme leaps with the piano lower voiced rhythmic stomping. (C) 2015 by Theodore Presser Company

\section{SUMMARY}

As a tone poem, Wish Sonatine exemplifies a hybrid of music and text. The work personifies Coleman's compositional approach to tonal imagery and integration of non-Westernbased rhythmic and melodic motifs. The hybridity in the piece is exhibited through her use of harmonies that are usually reserved for stylistic mediums such as African-American spirituals and jazz. Coleman's implementation of extended flute techniques displays her knowledge of the instrument. Understanding this imagery and these references can help a flutist who is learning the piece to create their own interpretation. Whereas a deeper theoretical approach would be outside the scope of this research document, the interpretation-based analysis highlights more fully the specific examples of hybridity in terms of stylistic musical elements and narration of the poem.

\section{BACKGROUND OF FANMI IMÈN FOR FLUTE AND PIANO}

Fanmi Imèn exhibits similar characteristics to nineteenth-century tone poems through its musical form and subject matter. A single continuous movement, Fanmi Imèn evokes the content 
of American poet, singer, and civil rights activist Maya Angelou's poem, "Human Family." As in other tone poems, the piece is intended to inspire the performer and listener to imagine the picturesque scenes, ideas, and moods illustrated by the poem. Coleman achieves these images through various motifs that she develops throughout the piece. The composition's framework consists of melodic motifs representing the various cultural differences and themes presented in the poem, creating a musical journey through the continents of North America, Asia, Africa, and Europe.

Fanmi Imèn was commissioned by the National Flute Association for the 2018 High School Soloist Competition to be performed by eight finalists at the convention in Orlando, Florida. Coleman was contacted by Dr. Lisa Bost-Sandberg, who served as chair of the 2018 NFA New Music Advisory Committee, to compose an advanced high school level piece no longer than eight minutes. The title of the piece is the Haitian Creole translation of Maya Angelou's poem "Human Family" on which the composition is based (Figure 4.9). In the poem, Angelou addresses the various differences that people have used to compare themselves to one another throughout the human family: personalities, geographic locations, appearances, and nationalities. These themes of subtle differences are prevalent throughout the poem, however, at the end Angelou declares that despite our differences, the human family is more similar than different. The poem concludes with the repetition of the line, "we are more alike, my friends, than we are unalike," encapsulating the ideals of unity within the human race. ${ }^{25}$ It is this repetitive line that sparked the inspiration for Coleman to compose this work. ${ }^{26}$

\footnotetext{
${ }^{25}$ Maya Angelou, "Human Family," in I Shall Not Be Moved (New York: Random House, 1990), 4.

${ }^{26}$ Coleman, interview with Trotter.
} 


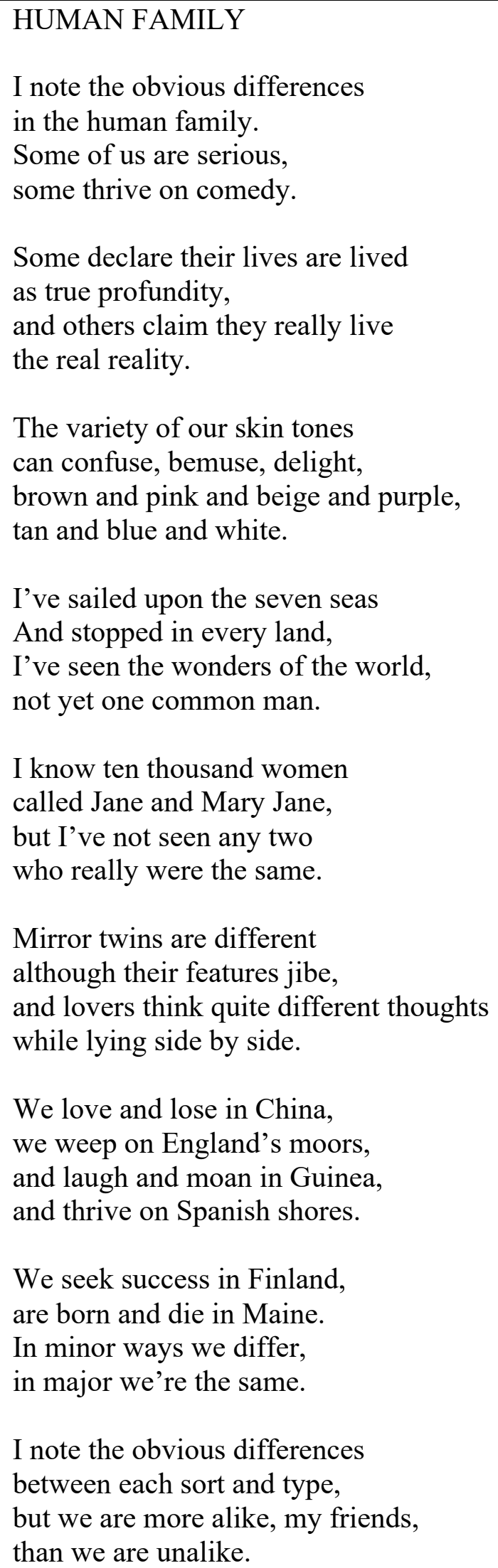


We are more alike, my friends, than we are unalike.

We are more alike, my friends, than we are unalike.

Figure 4.9. "Human Family" from I SHALL NOT BE MOVED by Maya Angelou, copyright (c) 1990 by Maya Angelou. Used by permission of Penguin Random House LLC. All rights reserved.

\section{ANALYSIS OF FANMI IMÈN FOR FLUTE AND PIANO}

In regards to the form of the piece, Coleman states, "To me, it does not intentionally prescribe to any traditional form, but I am sure there are indirect parallels to concours French flute music, as that is what I grew up with in my training as a flutist." 27 The indirect parallels of concours French flute music can be seen in Fanmi Imèn's function as a competition piece. While not intentionally having a form, the work does present four distinct sections with the last section serving as a combination of the previous three (Figure 4.10). In a similar fashion as Wish Sonatine, the piece's thematic materials are derived from the various melodic and rhythmic motifs presented in both the flute and piano which bring a wide range of stylistic elements of American, Middle Eastern, Asian, African, and Latin musical cultures.

\begin{tabular}{|l|l|l|l|}
\hline Measures & Form & Stylistic Tempo Marking & Motifs \\
\hline mm. 1-37 & A & $\begin{array}{l}\text { Sacred }(\mathrm{d}=72) \\
\text { Poco rubato ma non troppo } \\
\text { Poco più mosso }(\mathrm{d}=80)\end{array}$ & $\begin{array}{l}\text { Fanmi Imèn } \\
\text { (flute \& piano) }\end{array}$ \\
\hline mm. 38-90 & B & Traveling (half note $=78)$ & Hallelujah (flute) \\
\hline
\end{tabular}

${ }^{27}$ Coleman, interview with Trotter. 


\begin{tabular}{|c|c|c|c|}
\hline & $\begin{array}{r}\text { Key Area: } B b \\
\text { minor }\end{array}$ & & \\
\hline mm. 91-97 & $\begin{array}{l}\text { Transition } \\
\text { Key Area: D Major }\end{array}$ & Pensive $(d=72)$ & $\begin{array}{l}\text { Fanmi Imèn } \\
\text { (flute \& piano) }\end{array}$ \\
\hline mm. 98-104 & $\begin{array}{l}\text { Accompanied } \\
\text { Cadenza }\end{array}$ & $\begin{array}{l}\text { Rubato, in style of Flamenco cante } \\
\text { and toque } \\
\text { Fierce! }(d=128) \\
\text { Rubato e molto accelerando }\end{array}$ & \\
\hline $\begin{array}{l}\mathrm{mm} .103- \\
153\end{array}$ & $\begin{array}{l}\text { C } \\
\text { Key Area: D Major }\end{array}$ & A tempo, fierce $(\mathrm{d}=128)$ & $\begin{array}{l}\text { Unity (flute) } \\
\text { Kalimba (piano) }\end{array}$ \\
\hline $\begin{array}{l}\mathrm{mm} .154- \\
182\end{array}$ & $\begin{array}{l}\text { Combination of } \\
\text { A \& B \& C } \\
\text { Key Areas: } D \\
\text { Major, Ab Major, } \\
\text { Db Major }\end{array}$ & $\begin{array}{l}\text { A tempo, fierce }(d=128) \\
\text { Presto }(d=138+) \\
\text { Presto }(\text { half note }=92)\end{array}$ & $\begin{array}{l}\text { Fanmi Imèn } \\
\text { (flute \& piano) } \\
\text { Unity (flute) } \\
\text { Hallelujah (flute) }\end{array}$ \\
\hline
\end{tabular}

Figure 4.10. Form Chart for Fanmi Imèn poem for flute and piano ${ }^{28}$

The compositional structure of Fanmi Imèn reveals a systematic use of developing short melodic and rhythmic motifs that appear throughout the composition (Figure 4.10). These motifs serve as a way to unify a diverse mosaic of musical identities from America, the Middle East, East Asia, and Africa. ${ }^{29}$ In addition, the motifs also emphasize the ideals set forth in the poem. For example, the pitch structure of the Fanmi Imèn motif (consisting of B-F\#-C\#) can be seen in many of the other motifs I have documented in Figure 4.11. The pitches C\# and B, which are important to the Fanmi Imèn motif are important in the motivic development throughout the piece. The unity motif presents the same pitches, but with a prolongation of the C\#. Similarly, the Kalimba motif contains the same rising perfect fifth between the F\# and C\# and the fall to the $\mathrm{B}$, but embellishes it with an E. I interpret the relationship of these motifs to the Fanmi Imèn

28 The names of the motifs are a mixture of my interpretation and descriptions from Valerie Coleman's liner notes.

${ }^{29}$ Valerie Coleman, Fanmi Imèn, (Malven: Theodore Presser Company, 2018), 1. 
motif as a reflection upon the underlying themes of the poem, acknowledging Angelou's intentional inclusion of the word "family" rather than "race" or "species" to symbolize that all people can relate to one another. One could interpret this overarching unity as a sly homage to the eighth stanza of the poem (Figure 4.9).

\begin{tabular}{|l|l|l|}
\hline Motif \\
(flute \& piano)
\end{tabular}

Figure 4.11. Motif chart of Fanmi Imèn poem for flute and piano ${ }^{30}$ - (C) 2018 by Theodore Presser Company

Coleman describes the opening section of the piece as having a "patriotic Americana feel, to symbolize and recognize the contributions immigrants have made towards the building of the nation as a whole." ${ }^{31}$ I believe that the patriotic mood is presented by the Fanmi Imèn motif because of its open fourths and fifths that are reminiscent of the Americana of Aaron Copland. ${ }^{32}$ The motif, containing only three pitches, is presented four times accompanied by a delicate

${ }^{30}$ The names of the motifs are a mixture of my interpretation and Valerie Coleman's liner notes descriptions.

${ }^{31}$ Coleman, Fanmi Imèn, 1.

${ }^{32}$ See for instance, Aaron Copland's Duo for Flute and Piano (1971). 
glissando in the piano within the first stylistic tempo marking of Sacred. The reoccurrence of the motif is altered slightly in intervals, rhythms, and pitches yet still retains its distinct features (Figure 4.12).

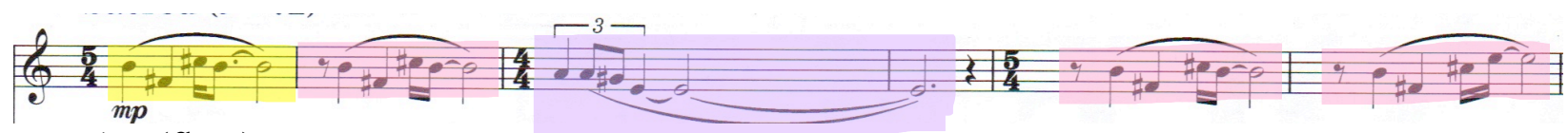

mm. 1-5 (flute)

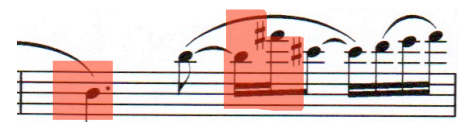

m. 10 (flute)

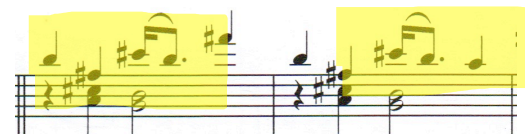

mm. 16-17 (piano)

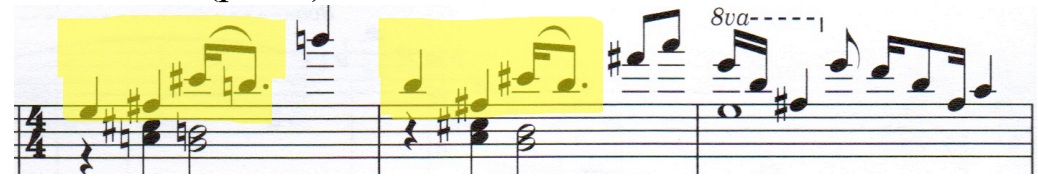

mm. 21-22 (piano)

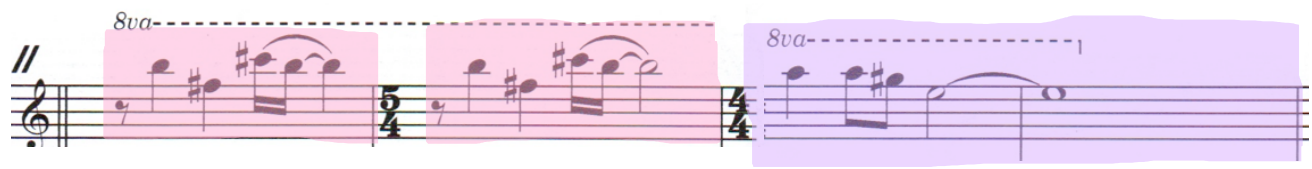

mm. 91-93 (piano)

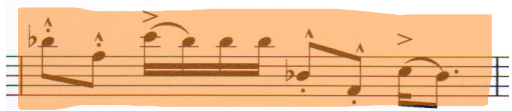

m. 138 (flute)

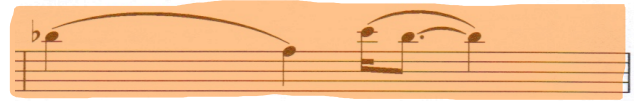

mm. 156 (flute)

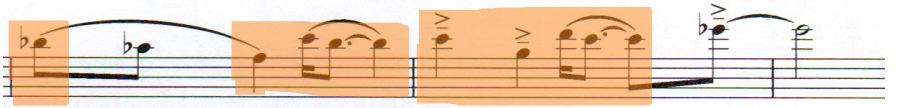

mm. 158-160 (flute)

Figure 4.12. Fanmi Imèn: Paradigmatic diagram of Fanmi Imèn motivic development. (C) 2015 by Theodore Presser Company. 
As Coleman describes the introduction, "I simply wanted a noble melody that was intended to globally reflect Maya's quote, 'We are more alike, my friends, than we are unalike.' I went 'by ear' with each of these motifs, with the intent of finding connecting threads. Pentatonicism and the use of ostinato as a means of motion are for sure connecting threads. I wish I could say more, but it is really intuitive based composing." 33

This Americana feel of the first section of the piece is bolstered by the jazz harmonies of the piano, which plays a progression which begins with a Bmin/E (vi), moves to $\mathrm{E}(\mathrm{V} / \mathrm{V})$, and ends on a GMaj7\#11 within the key of D major. This increases the Americana feel by representing an American popular musical genre. In various ways, Coleman gives a nod to the first stanza of the poem through the repetition of the Fanmi Imèn motif that represents the first two lines, and the playful/serious melodic materials presented in the Sacred and Poco più mosso sections that represents the last two lines (Figure 4.9).

In contrast, the B section marked as "traveling" presents three new melodic motifs representing diverse musical styles that are reminiscent of the fourth stanza of the poem (Figure 4.9). In this section, Coleman creates an allusion to traveling across the world through the rapid succession of short gospel-inspired dance-like thematic materials. The imagery of traveling is characterized by the flute's continuous rhythmic pulse in both the melodic flourishes and a short bridge of new thematic material in measure 71 . I contend that the new thematic material presents something akin to a spiritual interposed within the piece. The insistent repetition of a two-bar melodic phrase in the flute accompanied by a rhythmic ostinato in the piano is bolstered by the

\footnotetext{
${ }^{33}$ Coleman, interview with Trotter.
} 
climactic display of the extended flute techniques of singing and playing at the same time, flutter tongue, and is accompanied by the sforzando stomps in the piano (Figure 4.13). These vociferous elements are characteristic traits of the "noise" timbre that arises in popular American genres by African-American artists. ${ }^{34}$ This rambunctious gospel celebration represented in the singing and playing of the flute is presented as a small melodic fragment in measure 63 and is further developed throughout the section. This motif, which I have labelled as "hallelujah," occurs as the final gesture of the piece in a celebratory fashion (Figure 4.14).
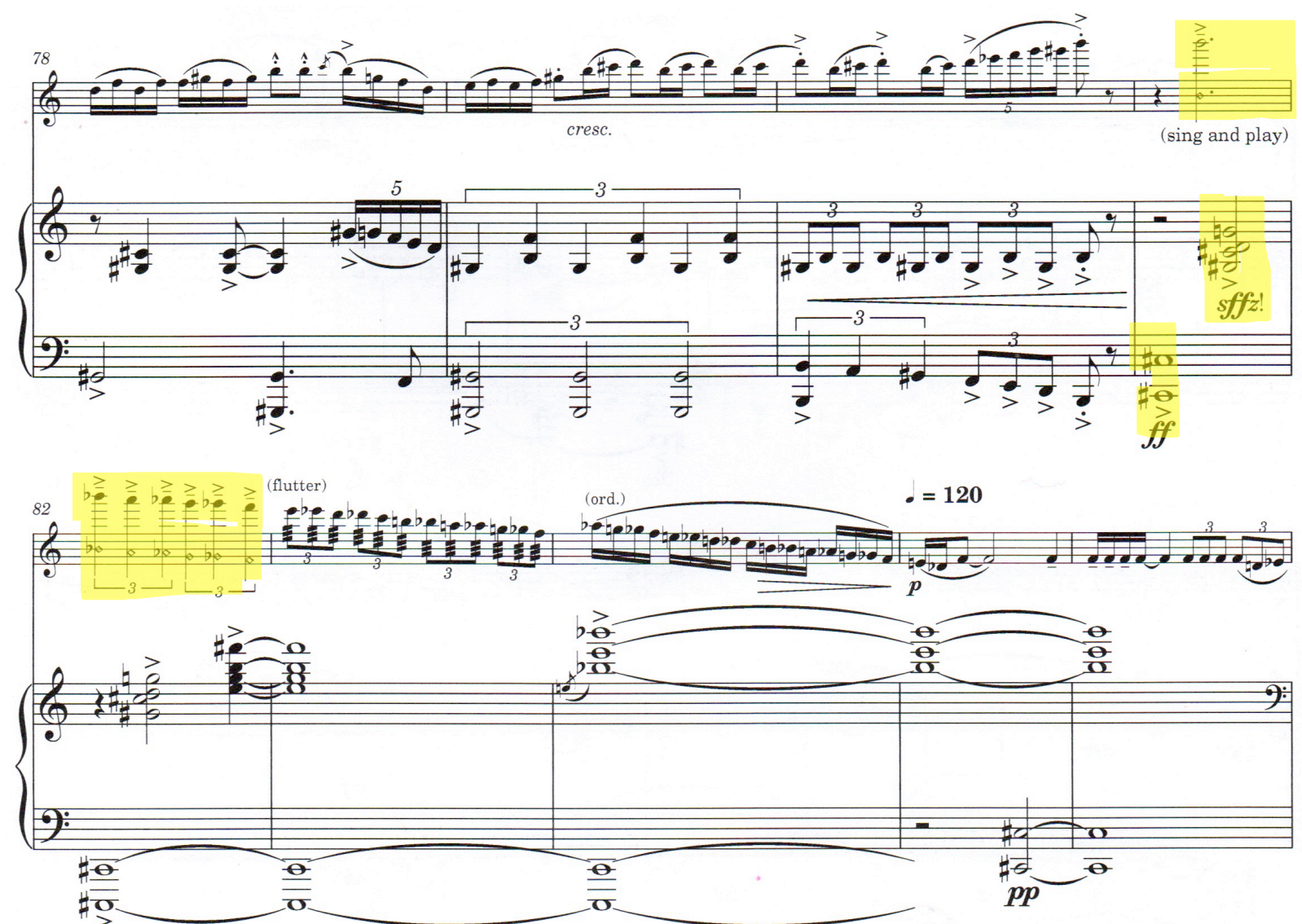

Figure 4.13. Fanmi Imèn: mm. 78-86, Hallelujah thematic material. (C) 2015 by Theodore Presser Company

34 Wesley Morris, "Why is Everyone Always Stealing Black Music?" The New York Times Magazine (August 8, 2018), https:/www.nytimes.com/interactive/2019/08/14/magazine/musicblack-culture-appropriation.html. 


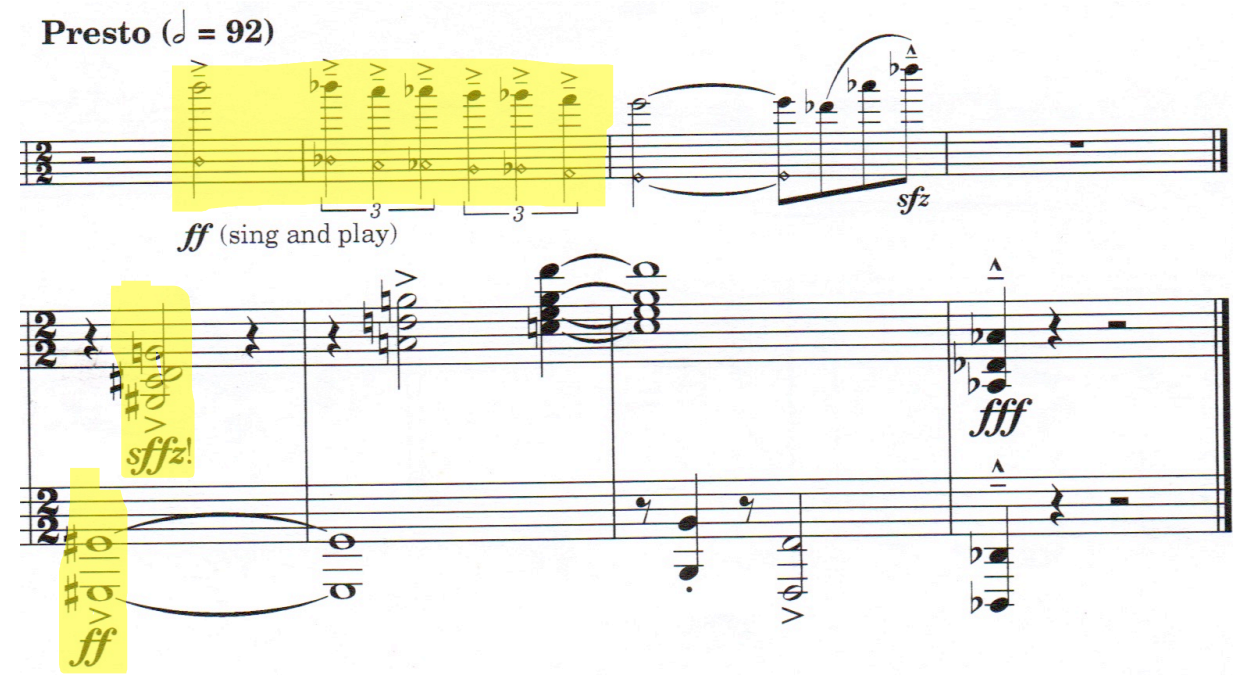

Figure 4.14. Fanmi Imèn: mm. 180-183, reoccurance of Hallelujah thematic material. C 2015 by Theodore Presser Company

The Pensive section marks a quick transition back to the original thematic material as the piano transposes the Fanmi Imèn motif to D major. The sections gradually transform into an accompanied cadenza in the style of Flamenco. The cadenza is reminiscent of another staple flute work, François Borne's (1840-1920) Fantasisie brillante on themes from Bizet's Carmen (1875) with its flamenco-esque expressive singing style, hard rhythmic phrasing, and accents. As an accomplished flutist, Coleman would have prior knowledge of this piece, however, the similarities are most likely coincidental.

The unity and kalimba motifs are presented in the last contrasting section of the piece. The two motifs are intertwined with each other to recreate the sounds of Africa using the traditional instruments of the Kalimba (thumb piano) and the djembe drum. The unity motif played by the flute imitates the kalimba as it spells out the word "unity" in Morse code. ${ }^{35}$ The

35 Coleman's incorporation of the rhythmic ostinato patterns of Morse code is inspired by her interest in the telecommunication character encoding system which she also uses in her other works such as Bronzeville, where she used the words "sisters," "Bronzeville," and "God" to create 
African themes continue in the Kalimba motif in the piano which is accompanied by a preview of an expanded development of the gospel spiritual bridge presented earlier in the piece. Since the reappearance of this bridge is clearly related, yet different from the original, it could be seen as a subtle nod to the words of the fifth stanza of the poem (Figure 4.9).

The last section of the piece serves as a combination of the previous sections, and forms a reunion of the different motifs and their representations within the poem. As stated earlier, the pitches and intervallic structure of the Fanmi Imèn motif are infused within the other motifs. This coming together of the motives supports the overarching theme of unity within the piece and poem. Fanmi Imèn illustrates the mélange of cultural influences that permeate the fabric of our daily lives, and Coleman has forged an amalgam of diverse musical elements to reaffirm her hopes and goals for unity.

\section{SUMMARY}

Fanmi Imèn exhibits hybridity through its blending of modern Western musical idioms with distinct elements of American, Middle Eastern, Asian, African, and Latin cultures. Coleman exquisitely balances these diverse styles, using melodic and rhythmic motifs to create a cohesive unifying composition. Inspired by Maya Angelou's poem “Human Family”, Coleman's use of tone poetry to evoke the essence of the text presents another element of hybridity in the work. The diverse mosaic of stylistic musical features resonates with the theme of unity from the poem. Coleman's flutist/composer duality is evident in her clear and precise instructions for her performer in the score marking, the detailed liner notes, and most of all the idiomatic writing of the piece. Fanmi Imèn evokes a celebratory embrace of cultural difference and fusion of

rhythmic ostinatos. Further explanation of the inclusion of Morse code can be reference to Valerie Coleman, Fanmi Imèn, (Malven: Theodore Presser Company, 2018). Liner Notes. 
transculturalism that can only originate from a composer who "digs deep" and "listens for the soul" in composing. "Her music is exactly the person that she is," Ellis remarks, "She is complicated, beautiful, down-to-earth, and it is just this incredible interesting combination of all these ingredients that make up her and it is evident in her compositions." ${ }^{36}$

${ }^{36}$ Ellis, interview with Trotter. 


\section{CONCLUSION}

Wish Sonatine and Fanmi Imèn represent Coleman's self-described hybrid "urbanclassical" style through her integration of text, culturally-relevant themes, and blending of traditional Western styles with the popular genres of jazz, blues, spirituals, along with nonWestern musical influences from African, Middle Eastern, and Asian culture. Both works celebrate a diverse heritage, contributing to Coleman's vision of more diverse representation in classical music.

The various influences which encapsulate much of her compositional writing are a manifestation of ideals, places, and people who influenced her as both a flutist and composer. This is in tune with her compositional process of "digging deep," which involves both intuition and vulnerability. As Coleman expresses, "I hope that my music is a reflection of the times we live in and will serve as a historical place marker for future reference. Further, I believe it necessary to share the experiences and history of the diaspora in a medium that connects to everyone."1

Coleman's compositional style is inspirational and has a prominent position among other voices of the contemporary music community. With her recent accomplishments and accolades, this research will not only serve as a source of information to help inform interpretations of her flute works, but also become a catalyst for similar study of her other works. For example, a comprehensive analysis of musical hybridity elements in her chamber, orchestral, and instrumental works would prove indispensable in further identifying other hybrid compositional characteristics. Although Coleman is relativity early in her career, her current achievement and

\footnotetext{
${ }^{1}$ Valerie Coleman, interview with Brittany Trotter, November 24, 2019.
} 
accolades are noteworthy. While her music may be termed as accessible and transcultural, such descriptions should not suggest a depreciatory connotation. Coleman places great emphasis on reaching new audiences and mentoring the next generation of musicians. She states, "When things become more inclusive on a musical level then the artistry has room to grow. I go back to this idea of path. One needs to expand the path for musicians to grow." ${ }^{2}$ Through her music and vision, Coleman has created a legacy of inclusion that breaks down cultural and social barriers, contributing to the establishment of a diverse modern era of classical music. Understanding how hybridity and identity is integral to Coleman's compositional style will help performers understand the voice and message of this remarkable composer, and perhaps open the door for further study of pluralism and hybridity in the works other living composers. This document serves as an important step toward that goal.

\footnotetext{
2 Maya Bell, "Expanding the path for musician," University of Miami News, October 14, 2019, https://news.miami.edu/stories/2019/10/expanding-the-path-for-musicians.html.
} 


\section{APPENDIX A}

\section{Defining Hybridity}

The modern connotation of hybridity is a paradoxical notion. Rather than being a single idea or a united concept, the notions of difference, otherness, belonging, and the process of being mixed are recurrent in descriptions of hybridity in scholarly discourse. ${ }^{1}$ Hybridity is a popular idea in various academic disciplines, particularly within the social sciences and humanities. Given the intense interest in hybridity across a broad spectrum of disciplines, the meaning of the term in current literature is somewhat abstract despite its origins. To better understand the term's ambivalence, here are some examples culled mainly from disciplines within the humanities.

1. Hybridity is "a concept for describing musical mixtures that are explicitly enmeshed in identity politics, most often involving racial and ethnic identity, and its effects on culture." 2

2. Hybridity is "a theoretical orientation that characterizes cultural processes and change as based on open-ended and ongoing intermingling and fusion." 3

3. Hybridity is "a term used in contemporary Postcolonial Studies to theorize and to a certain degree celebrate a global state of mixedness - a mixedness of cultures, races, ethnicities, nations, and so on." 4

4. "The concept of hybridity involves the amalgamation or combination of previously distinct elements into a new variation."

5. Hybridity is "a condition arising from the mixing and transcendence of binary opposites such a nature-society, or colonized-colonizer." 6

6. Hybridity is "the mixture of meanings that emerges when two cultures interact; the new forms that are created when cultures merge." 7

1 Jin-Ah Kim, "Cross-Cultural Music Making«: Concepts, Conditions and Perspectives." International Review of the Aesthetics and Sociology of Music 48, no. 1 (2017): 20.

${ }^{2}$ Kariann Goldschmitt, "Hybridity," in The Grove Dictionary of American Music Online $2^{\text {nd }}$ ed., ed. Charles Hiroshi Garrett (Oxford University Press, 2013)..

${ }^{3}$ Luis Vivanco, "Hybridity," in A Dictionary of Cultural Anthropology (Oxford University, 2018).

${ }^{4}$ Ian Buchanan, "Hybridity," in A Dictionary of Critical Theory (Oxford University Press, 2018).

${ }^{5}$ T. R. Kover, "Hybridity," in Berkshire Encyclopedia of Sustainability (Berkshire Publishing Group, 2010)

6 Alisdair Roger, Noel Castree, and Rob Kitchin, "hybridity." In A Dictionary of Human Geography (Oxford University Press, 2013).

${ }^{7}$ Susan Mayhew, "hybridity, "in A Dictionary of Geography (Oxford University Press, 2015). 
7. Hybridity "acknowledges that identity is form through an encounter of difference." 8

8. Hybridity is "the synthesis that takes place in any encounter between distinct cultures, with the implication that combination, rather than sorting into pure categories, is the norm." $" 9$

9. Hybridity is "an association of ideas, concepts, and themes that at once reinforce and contradict each other." 10

The range of complexity and difference among these various formulations is remarkable and, in part, reflects the multiple lineages that "hybridity" has within disciplines. Given the current trends of modern Western society towards tolerance and multiculturalism, the popular discourse on hybridity commonly characterizes the term as progressive, alliance-building, anti-imperialist, and subversive. ${ }^{11}$

From the Latin derivative hibrida, denoting the cross between two separate plants or animal species, to its contemporary cultural construct as a tool for racial discourse, hybridity has salience in academic and popular culture. ${ }^{12}$ From biology to cultural studies, hybridity has been used in a variety of contexts as an apparatus to bolster both political and ideological theories. Often, these theories contradict one another depending on the perspectives of the interpreter. Despite these contradictions, most scholars agree that hybridity could be used as a conceptual frame work to investigate and deconstruct both structural and imaginary boundaries due to geographic, economic, and/or cultural factors, and to highlight either positive or negative connotations and values. ${ }^{13}$

8 "Hybridity," in A Dictionary of Sociology, ed., John Scott (Oxford University Press, 2014). 9 "Hybridity," Oxford Reference (2002).

10 Marwan M. Kraidy, Hybridity (Philadelphia: Temple University Press, 2005), vi.

11 Michael Syrotinski, "Hybridity Revisited," in Deconstruction and the Postcolonial: At the Limits of Theory (Liverpool: University Press, 2017), 26.

12 The offspring of a (female) domestic sow and a (male) wild boar. Reference to Brian Stross, "The Hybrid Metaphor: From Biology to Culture." The Journal of American Folklore 112, no. 445 (1999): 254.

${ }^{13}$ Bruno Moschine Alcalde, "Patterns of Hybridity: An Analytical framework for Pluralist Music" (PhD diss., Northwestern University, 2017), 21. 
Culture theorists have dated the usage of hybridity in describing the mixture of cultures, specifically ethnicity, class, and nationality to the early twentieth century. Prior to the assimilation of social Darwinism, classifying humans by "race" was a common practice within Western European culture as shown by the studies of J.F. Blumenbach, J.A. Compte de Gobineau, Georges Cuvier, Charles White, and Robert Knox. ${ }^{14}$ In Colonial Desire, Robert J.C. Young (1995) examines the origins of hybridity through the lens of racial theory. According to Young, the concept of hybridity was used to provoke a fear of miscegenation in the European dominant class by proposing that humanity was composed of different species. In this way, the notion of hybridity was essential in defining the separation and mixture of dominant and subdominant racial identities. For decades, hybridity was used to create a fear of impure ethnicity that was exerted by a pseudo-scientific argument to justify the supremacy of ideologies, identity, and status of the dominant European societies compared to non-European societies. Social sciences scholars in the late twentieth century engaged in the problematic concepts of hybridity specifically depending upon the contexts and ideology supporting the argument. These concepts, which appear in many academic works, became the catalyst for much of the dissent and difference of opinions in the interpretation of hybridity in postcolonial studies.

In some fields in the latter half of the twentieth century, the pejorative definition of hybridity changed to one of inclusion. Referring to the discourse of hybridity and its attachment to racial and cultural identity, Jan Nederveen Pieterse (1996) mentions:

Hybridisation offers an antidote to the cultural differentialism of racial and nationalist doctrines because it takes as its point of departure precisely those experiences that have been banished, marginalized, tabooed in cultural differentialism. It subverts nationalism because it privileges border crossing. It subverts identity politics such as ethnicity or other

${ }^{14}$ Avar Brah, and Annie Coombes, "Hybridity and Its Discontents: Politics, Science, Culture (London: Routledge, 2000), 3. 
claims to purity and authenticity because it starts out from the fuzziness of boundaries, from boundary crossing. ${ }^{15}$

Thus, the phenomenon of hybridity has been a prominent element in cultural and postcolonial studies, however its variable interpretation and the deployment of its usage has generated a seemingly infinite range of theories. Generally, the discourse within these disciplines employs the term "hybridity" to refer to the alterity (otherness) of race, ethnicity, gender and class. ${ }^{16}$ Postcolonial theory is modeled on postmodernism, with which it shares certain approaches in concepts and methods. ${ }^{17}$ Originating in 1978 with the publication of Edward Said's Orientalism, postcolonial studies examine the political, social, economic, and cultural effects of colonialism on both the colonized and colonizing groups. ${ }^{18}$

The adaptation of hybridization in postcolonial studies has allowed scholars to examine specific cultures in case-by-case studies to identify various perspectives and interpretations. For instance, both Alberto Moreiras (2010), who studies hybridity in Latin America in Hybridity and Double Consciousness, and Paul Gilroy (1993), in his research of the African diaspora in Black Atlantic: Modernity and Double Consciousness, present the concept of "double consciousness," to examine the flow of people, ideas, and cultures. ${ }^{19}$ These concepts of the transfer of cultural commodities between borders and boundaries and the effects it has on both sides have been discussed by scholars by connecting hybridity to processes of globalization. Jan Nederveen

15 Jan Nederveen Pieterse, "Globalization and Culture: Three Paradigms", Economic and Political Weekly 31, no. 23 (June 8, 1996): 1392.

${ }^{16}$ David Beard, and Kenneth Gloag, Musicology: The Key Concepts (London: Routledge, 2016), 199.

17 Amar Acheraiou, Questioning Hybridity, Postcolonialism and Globalization, (Houndmills, Basingstoke, Hampshire: Palgrave Macmillan, 2011), 144.

18 S. Shankar, "The Origins and Ends of Postcolonial Studies," Ariel 30, no. 4 (October 1999): 143.

${ }^{19}$ See Michael Syrotinski, "Hybridity Revisited," In Deconstruction and the Postcolonial: At the Limits of Theory, (Cambridge: Liverpool University Press, 2007), 35. 
Pieterse and Marwan Kraidy (2005) address hybridity as it relates to globalization in regards to the clashing notions of cultural differentialism and convergence within modernization. ${ }^{20} \mathrm{Kwame}$ Anthony Appiah (2006) expanded this concept by advocating for a cosmopolitanism viewpoint toward an individual's mixture, modernity, and rights to create what he calls contamination, his term for healthy hybridization that turns away from the concepts of purity, peoples, authenticity, tribalism, and cultural protections. ${ }^{21}$

Given its ambivalence, the concept of hybridity has seen criticism from scholars within the disciplines of postcolonial and cultural studies. Described as a "risky notion" by Kraidy, the number of competing definitions and nuances can be used to obscure an argument. ${ }^{22}$ This "antihybridity backlash" as Kraidy explains it is due to two issues. First, hybridity seems at once to be both marginal and all-encompassing. Second, the openness of the term can lead to "arbitrary and...exclusionary usage." ${ }^{23}$ Young and Mikhail Bakhtin employ these inconsistencies in their criticism to describe how hybridity is often politicized within postcolonialism conceptions in order to undermine and dispute division and separation. ${ }^{24}$ According to Young, the contemporary cultural discourse of hybridity cannot escape the connection with the racial categories of the past

20 See Marwan Kraidy, Hybridity (Philadelphia: Temple University Press, 2005) and Jan Nederveen Pieterse, "Globalisation and Culture: Three Paradigms, "Economic and Political Weekly, vol. 31, no. 23 (June 1996): 1389-1393.

${ }^{21}$ Willie Smyth, review of Cosmopolitansim: Ethics in a World of Strangers, by Kwame Anthony Appiah, Western Folklore 68, no. 1 (Winter 2009): 78-80.

${ }_{22}^{22}$ Marwan Kraidy, Hybridity (Philadelphia: Temple University Press, 2005), vi.

${ }^{23}$ Ibid., 65-66.

${ }^{24}$ See Robert Young, Colonial Desire: Hybridity in Theory, Culture, and Race (London: Routledge, 1995) and Mikhail Bakhtin, The Dialogic Imagination: Four Essays (Austin: University of Texas Press, 1981). 
in which hybridity was associated with clear racial meaning. ${ }^{25}$ Johnathan Friedman (1999)

contributes to this criticism by stating,

Hybridity only exists as a social phenomenon when it is identified as such by those involved in social interaction. This implies that where people do not so identify, the fact of cultural mixture is without social significance... hybridity is in the eyes of the beholder, or more precisely in the practice of the beholder. ${ }^{26}$

This criticism draws from the objection that in a sense, all culture is hybrid and was arguably always hybrid. One may draw a similar conclusion in reference to hybridity in music. In the case of Ravel's statement presented in chapter 2, he considered his music to be a product of his own creation and the developmental growth of Western music. Despite these criticisms, the general argument I have presented in this research concludes that hybridity is indeed a form of identity and is worth exploring within musical discourse.

Recent contributions in hybridity as it relates to cultural diversity have led to scholars such as Michael Syrotinski (2007) depicting hybridity as synonymous with words like multiculturalism, transculturalism, and other notions of hybridity as a type of cultural diversity. ${ }^{27}$ This concept tends to endorse the celebration of cultural difference and fusion which draws criticism from scholars who contest that it does not give adequate attention to economic, political, and social inequalities. ${ }^{28}$ Annie Coombes and Avtar Brah (2005) explain that it is "imperative to situate every analysis of hybridity in a specific context where the conditions that

\footnotetext{
${ }^{25}$ Robert Young, Colonial Desire: Hybridity in Theory, Culture, and Race (London: Routledge, $1995), 615$.

${ }^{26}$ Johnathan Friedman, "The Hybridization of Roots and the Abhorrence of the Bush" in Spaces of Culture: City, Nation, World, ed. Mike Featherstone and Scott Lash, 230-256, (London: SAGE Publications Ltd, 1999).

27 Syrotinski "Hybridity Revisited," 28.

${ }^{28}$ See Avtar Brah and Annie Coombes, Hybridity and its Discontents: Politics, Science, Culture (London: Routledge), 1; Marwan Kraidy, Hybridity (Philadelphia: Temple University Press, 2005), vi.
} 
shape hybridities are addressed." ${ }^{29}$ That is, hybridity should not be presented as a onedimensional description of culture.

The theories of and approaches to hybridity in biology, postcolonial studies, and cultural studies have influenced musicologists and ethnomusicologists to contribute perspectives of hybridity in Western art music. While this appendix presented a brief survey of scholarship in these fields, many aspects comparably coincide with the current discourse of hybridity in music. In fact, one could argue that the gradual globalization of the East starting from the seventeenth century to the present resulted in the blurring of cultural and musical boundaries in Western art music. This is evident in compositional techniques that have evolved over styles and genres as I presented in my research.

${ }^{29}$ Kraidy, Hybridity, vi. 


\section{APPENDIX B \\ CORRESPONDANCE WITH VALERIE COLEMAN \\ 11/24/2019 - EMAIL CORRESPONDANCE}

VC: Valerie Coleman

BT: Brittany Trotter

BT: In an interview with Heidi Kay Begay on the podcast Flute 360, you mentioned that your compositional process requires "digging deep." Could you comment more on what "digging deep" means?

VC: To me, the act of creating a new work is an incredibly personal process, in which I have to allow myself to become vulnerable and quiet so that my heart, spirituality, emotions and analytical mind can "click in" and communicate with my subconscious (light bulb moment). Digging deep means forcing myself to undergo this process, by removing outside interference and distraction in order to find headspace.

BT: Do you put a "piece" or "persona" of yourself, either consciously or subconsciously, in your works?

VC: Since my work is intuition and inspiration based, it always has the investment of conscious and unconscious vulnerability that comes from achieving a state of flow, which is why headspace is critical to the process. Each work always carries either or both joy and sorrow from a personal perspective, as well as either memories or "visualization" of what the premiere performance would look like.

BT: In reflecting upon the great flutist-composers of the past, such as Moyse, Taffanel, and Guabert, what do you perceive to be your unique contributions to the flute or do you consider your work as simply building upon the previous repertoire? 
VC: I cannot fully answer that myself as it remains to be seen, but I hope that my music is a reflection of the times we live in and will serve as a historical place marker for future reference. Further, I believe it necessary to share the experiences and history of the diaspora in a medium that connects to everyone.

BT: What would you say is one characteristic from Moyse, Taffanel, Guabert, or any other flutist-composer that you similarly identify with in your compositions?

VC: I am drawn to their sense of lyricism that allows the flute to be utilized with a singing quality, while highlighting its virtuosic attributes.

BT: Do you consider your compositional style to be a hybrid of non-Western music, American popular music, literary sources, French flute styles, and modern transcultural relevance?

VC: Yes, absolutely!!

BT: On your website, you have the following quote: "her style weaves inspired tapestries of urban-classical roots; living mosaics that connects culture and humanity." How would you define your "urban-classical" composition style?

VC: This is something that composers who write this way always struggle to define, as it is an often-intangible characteristic of the "Classical based music of now" that infuses the cultural experiences of the Diaspora and Latinx cultures. It has elements of obstinate grooves, blues harmony, spirituals, inflections of sorrow, influences of Gospel, R\&B, Motown and jazz. BT: What drew you to base or draw inspiration from Maya Angelou's "Human Family" in Fanmi Imèn? What aspect of the poem sparked a reaction for you to compose?

VC: I cannot remember how I came upon Dr. Angelou's poem, but the overarching meaning of the poem was the catalyst, not the verses. The last strain "We are more alike" however, was key to the spark. 
BT: Who contacted you about writing a new piece for the 2018 NFA High School Soloist Competition?

VC: Lisa Bost-Sandberg

BT: Were you given any guidelines by the NFA about the time limitation or any other aspects for the piece?

VC: Yes. It had to be no longer than $8 \mathrm{~min}$ and advanced high school level.

BT: Can you briefly talk about the different motives and their relation to pentatonicism, MiddleEastern flamenco music, kalimba thumb piano, and the Morse code unity motif?

VC: For the introduction, I simply wanted a noble melody that was intended to globally reflect Maya's quote, "We are more alike, my friends, than we are unalike. I went "by ear" with each of these motifs, with the intent of finding connecting threads. Pentatonicism and the use of ostinato as a means of motion are for sure connecting threads. I wish I could say more, but it is really intuition-based composing.

BT: I labelled a motif in Wish Sonatine as “cat o'nine tail.” Could you comment more on this motif?

VC: depicted throughout as 8th note high B's (and quick shrieking leaps like that), it happens at m.26, m. 36., m. 39, etc.

BT: I labelled a motif in Wish Sonatine as "moving water." Could you comment more on this motif?

VC: $\mathrm{m}$. 57. As the European ship sails off, I want to address the way European composers always depict water movement and mystery (Moldau), but give it a twist that denotes the presence of Africans as cargo. There is also the perspective of the enslaved people, a sense of 
wonder in not knowing where they are going, but also initial thoughts of trying to find ways off the boat.

BT: I labelled a motif in Wish Sonatine as "djembe drum." Could you comment more on this motif?

VC: The more common rhythms of the Djembe drums needed to be used in a way that there was no doubt that the flute IS the djembe.

BT: I labelled a motif in Wish Sonatine as "coercion and resistance." Could you comment more on this motif?

VC: Having the flute convey what are reactionary characteristics of a person going through trauma: shrieks of defiance through leaps in and out of the flute's upper register, hard articulations to emulate aggressive behavior, the piano part asking for an entire forearm to be slammed onto the piano keyboard.

BT: I labelled a motif in Wish Sonatine as "inner contemplation." Could you comment more on this motif?

VC: Simple spiritual-esque, bluesy melody, placed within a dark key.

BT: Would you consider the pitch bends in $\mathrm{m} .196$ to be a slave jumping ship?

VC: Jumping ship would be m. $191 \&$ 192. What you hear in m. 196 is moan from labor pain.

BT: I called the following a middle passage motif because it sounds like three bell tolls representing the three main ports of the Middle Passage. Was this your intention, if not, what are your thoughts on the idea?

VC: Yes, but it is also the main pivot to a transition into the next "vignette" of the story. 


\section{APPENDIX C \\ INTERVIEW WITH MONICA ELLIS \\ 10/29/2019 - 10:00AM EST, VIDEOPHONE INTERVIEW}

ME: Monica Ellis

BT: Brittany Trotter

BT: Do you consider Valerie's compositional style to be a hybrid of non-Western music, American popular music, literary sources, French flute style, and modern transcultural relevance? If so, how?

ME: She is definitely the type of composer who combines styles, but I wouldn't say- in my opinion - that it is a combination of non-Western styles. To me, at least, non-Western style or music implies music from the world outside that it is not from the European tradition. I guess in a sense, one could say she is combining the European traditional of classical with the America, as in the United States of America. I would say the combination, the hybridity, that exists - if it is anywhere - is truly from the right here in the US of A. To me, she is just so brilliant at finding sounds of this culture - of our culture here in the United States and the hybridization of that, I guess. So jazz, soul, R\&B, blues for sure, gospel. So those elements that are kind of American made music - American born music. It is that in combination to your so-called Western classical tradition is more of the hybrid versus a non-western. It is non-Western, but not in the way we assume it meant to be. You know what I mean?

BT: How would you define Valerie's "urban-classical” composition style?

ME: Yeah so, I think she and Jeff (French hornist in Imani Winds), who is also a wonderful composer and truly was inspired by Valerie's music and by her process, they both have this concept of urban classical. I think urban-classical is the influences of urban life, city life, the grit, 
the gravy, you know, just that hood spud of what you need to survive in a city setting versus a rural setting in the country. That vibe lends itself to a different influence. So again, just the city life. You know, the pull yourself up by the boot straps type. All of that influences and informs the music that she writes. But of course, she is so gifted. It happens in a very stylistic way, a very non-overt way. Sometimes it is very overt. Sometimes it is boom right in your face because she is trying to show and make that point with whatever music she is writing. In a lot of ways, it is not that deep. She grew up in an urban setting. She grew up in Louisville, KY, in Muhammad Ali's neighborhood. Growing up, she would hear sounds, the vernacular, and the soulfulness in the people. It is very clear in her music and you need to know this to understand the sensibility in her music. Those sounds include classical music because she grew up loving the flute. She grew up loving Brahms, and Beethoven, and Mozart. And at the same time, she heard gospel music, she heard blues, she heard pop and R\&B. Growing up as a child of the 70s and 80s, you listen to Michael Jackson so why not that? Jazz too of course. So, all of that music is heavily there.

BT: How would you describe her sense of cultural relevance to current events in her compositions?

ME: Like most sensitive composers who are aware or even woke (to use a vernacular of today) composers and artists, she uses what is going on around her as a way to inform her music- her art. I think she has been informed by certain events that have happened, but at the same time, I think her inspiration comes from all sorts of things not related to an event that has occurred. For instance, she wrote a piece called speech and canzone. It was her desire to use electronic in her music and she has not done that before. So instead of being random about it, she decided to use the speech by Robert Kennedy. He was at a presidential event and Martin Luther King had just died. That speech by Kennedy has become one of his best-known speeches. She utilized those 
words within the piece. In the second movement, she took snippets and Cesar Chavez and A. Philip Randolph who are just these incredible figures in history that was about social justice and human rights and women rights. She used their words and nest them in Morse code which is something she uses a lot in some of her other music. It is one of my favorite pieces by hers. It is very politically charged. It's very emotional because it is using of the words of Robert Kennedy.

So, was she writing that for a particular reason or occasion? Did something happened that influenced or prompted her to write it? Not necessarily, it was just her desire to use electronics. In this case, she wasn't just going to find some bleeps and blops on a computer and come up with some music. She wanted to write something that is a little more interesting and significantlymore powerful. So, I guess in that regards, she is writing music that has this incredible social conscious platform to it, but not because she has to be socially conscious. You know, she is inspired by that and really fired up by things. It is innate, it is organic, it is not something that is for a reason. The piece she just wrote last year [Phenomenal Women], she wrote it while she was in the group and left the group before it premiered which was bitter sweet. It is for wind quintet and orchestra. It is a incredible work that we just premiere and still perform. It's about all these amazing women - Maya Angelou, Serena Williams, and others. Hey, was she inspired or reacting to the women's movement? Not really, I do not think so at least. Are there certain things in the news cycle that are prevalent and in our face? Of course, but I do not think her music is reactionary as much as it is inspired by life. She is just this extraordinary talented person who has a lot to say. Her music is not for music sake, and I think as a really sensitive musician and artist we all have to be. We are naturally influenced by the world around us in a constant. Sometimes pieces do just come out that will be a reaction to a particular event or a history. But I think that 
the composers who are sustainable are the one that are constant making music that you feel that need to be made regardless of what is happening in the world.

BT: Do you think Valerie puts a "piece" or "persona" of herself, either consciously or subconsciously, in her works?

ME: You know, I actually think she is just herself all the time. You have to give her credit too for being that type of person. She is always herself whether we are sitting in a van travelling from Minneapolis, or on the stage of Carnegie Hall. I think what is so enduring about Valerie and subsequentially her music is that you get what you get all the time. There is no pretense. I do not think there is a persona, if I had to actually stay that. Her music is exactly the person that she is. She really is "what you see is what you get." She is complicated, beautiful, down-to-earth, and it is just this incredible interesting combination of all these ingredients that make up her and it is evident in her compositions.

BT: In your opinion, do you think Valerie considers herself to have a hybrid/dual identity as a flutist-composer? If so, how?

ME: I think the best way to compare her is to a jazz musician. This question does not come up in jazz music or, for that matter, in world music. The idea of the composer and the performer is really only an issue when we talk about classical music because I think over time (throughout the history of classical music) that this duality of being composer and a performer has separated and being strictly a composer has become a thing. For years that wasn't a thing. Mozart was a performer. He wasn't just a composer. He played his own music. Classical music has put this separation in the mix and more and more as time goes on, they are coming back together. They are melding again and she is right there in that mixed. 
When you think about it, people simply do not ask jazz musicians the questions of "Are you more of a composer than a performer?" People don't ask jazz musician that because they write music all the time. They are improvisors who are constantly writing all the time. There is a spirit of composing within the world of improvising. With Valerie, I think she lives categorically in that lane than classical because she does say there is a distinct duality. She doesn't consider herself as just a flutist or a composer. It is absolutely, $100 \%$ both.

Even now since she left the group, people would as us, "Oh, did she leave the group because she wanted to focus more on composing" and we say, "No," because she never did not focus on composing. She is performing and doing these solo recitals and teaching. She is still playing, I am sure, at the highest level because she has that integrity when it comes to her playing.

There is a sense of improvising in her music. She gave us (Imani Winds) that liberty over all the years that we were playing together. We had certain liberties with her music because she knows us so well. We had the luxury of doing different things with her music that she knew will still make it hers. You know, retain her ownership of it but still make it better. I was thinking just the jazz aspect of it, with this topic of duality, she would be more categorical as a jazz musician. Although I do not think she thinks of herself as that kind of person per say, but she has those characteristic that jazz artists have where you do not even wonder about are you a composer too. You know when you at a jazz gig, you bring tunes to rehearsals and you do not ever think, "Oh you are just a composer.” So yes, there we go. The duality is in full effect. It has always existed. She has always had a high level - she is one of those greats.

BT: What do you consider Valerie's Identities in Music and Music in Identities to be? 
ME: I think her role as a mother. I have to think it influences her writing. In fact, the Phenomenal Women piece, even though she had this desire as a woman - that position that you are - has always influenced her. But now having a daughter, a girl child that she is taking care of is influencing her too. I do have to say she has always identified with children. She was around kids her whole life. She grew up the youngest of three. She has two older sisters. She was just around a lot of children growing up. I think she just has that sensibility of being a care taker and a care giver. She wants to give the underdog a chance.

In regards to how being a mother influenced her work, I can think of one piece that she wrote for wind trio (flute bassoon and clarinet). Its three-movement work. She wrote the works slightly separate from one another in time and then decided to combine them into a suite. The middle movement was written after Lisa was born. It's a beautiful lullaby that is sandwich inbetween these two power house type pieces. It is a beautiful contrast to the other two movements, but that would have never happened unless she had her daughter. Just the sounds she had in her head was related to being a mom. So, that is absolutely a part of her identity. Another one is her Louisville heritage. She is a very proud Louisvillian. She grew up in the same neighborhood as Muhammad Ali. And just those sounds, you hear the vernacular, again it is the soulfulness in the people. It is just very clear in her music that her music needs to understand that sensibility. Like don't play her music without knowing something about her. Because you will miss something for one. Even if you do not have that experience, knowing the experiences of the composer, of her specifically, and that identity will really inform you to how to play it. It will be a more enjoyable experience for the performer knowing the identity as her as a composer.

Some composers are very literal and they want their music to be played exactly the way as it is written, and by the way that is great. I have no issue with that because as a performer and 
non-composer, you want that to be clear. You want the music to be clear because ain't nobody has time to be guessing. Here is the beauty of it, her music is clear- the physical scores - it is all right there. I think she composes her music as a performer. We have commission and read dozens of pieces over the years and we would often say, "Man, they just needed to give us more directions." I think that experience helped her to write clearly so her point would come across more efficiently. You do not want to have any unknowns in the mixed. However, knowing her as a person (or having some knowledge of her) is what inform our interpretation of her chamber works. Having all the ingredients on the page is important and, as a composer, she does that really well. But then, literally, the type of emotions that you give to a particular musical phrase, that is from knowing as much about the composer as you possibly can.

BT: Do you consider the following periods to be accurate in describing Valerie's career: 1) Imani Winds 2) Composition and University Teaching? How would you describe Valerie's experiences in Imani Winds (i.e. leadership, performing, composing, traveling, etc.) to have shaped the current period of her career?

ME: I would say so. We were just kids when we found each other. It is only when I talk about it in ways like this, that I have a moment of reflection. Cause otherwise, I am on the grind. We on the road on Thursday, for instance, and we will be out for the next two weeks. We will come back for a weekend and be gone again. So, you know, you are just doing it. But when I do have a moment to reflect on it, it's remarkable. And people say so all the time. They say, "Yeah y'all been this for a while, it's a big deal." And I know it is, but when you are in the mix of something - just the day to day of it - sometimes that big picture impact you differently. I enjoy talking about it for people like you who ask because it does give me that opportunity to reflect upon it. 
I think it was the definitive moment for all of us when Imani Winds started in 1997. We did a whole lot by her leadership and her vision. She is a huge visionary. So, I think that was a big phrase in her life, no doubt about it. I would say that what we build and created through her "brain child" as she says, gave her that platform to continue what she is doing now. The three of us who are still here (Toyin, Jeff and I), we are still doing what we doing. She is doing that now and doing it beautifully. In all honestly, I can't believe she is as busy as she is because I think part of why she left was because she sorts of not wanting to be on the road as much. She is definitely not, for sure. Even though she is performing and doing quite a bit of stuff, it is not like the group. And of course, being away from home. That was a tough one being away from the family. What she is doing now is just one performance here and there compared to a string of dates that keep you out for a week. That could be tough after a while. For sure, we built something that is incredible. Imani Winds can inequitably be described as her first big thing. It for sure guide her, I think, to where she is now.

Here is part of the reason why I think Imani Winds is such a tight knit group. We always had this idea that we are all in it together. Even when Valerie had these ideas about the festival or the commission project. These things that have sustain themselves. It was her idea, but we all gather around these ideas and did it as a group to manifest it. That is what I think is the beauty of the group. I think one of the best ways to maintain a chamber group is when each member has some sense of ownership. I am a leader when it comes to the business aspect, and the other leads in ways that are just as important. Of course, there will be times when there are more leadership duties for others, but we all had to continue to take on roles in the groups that would keep up moving forward. It been a DIY project since day one for sure, but we have recognized that we needed help from within and outside the group, and that has made it sustainable. I believe she 
left the group feeling that I think her "baby" would be in good hands. It is going to continue in the legacy that she hopes it would become. She embodied the group in so many ways and, in all honestly, continues to do so. We talk about he all the time because we play her music. She is still in the room and it's a beautiful thing.

BT: Could you elaborate on Valerie's compositional process (i.e. quiet space, writing retreat, research material)?

ME: She would do writing retreats occasionally. I think not as many as she wanted to. She would talk about the ideas coming into her mind. Some composers write it down immediately, while some try to remember. I do not think she did the writing things down quickly, but I guess she sort of remember. She has a great memory by the way too. She always talks about her having the luxury of having us as "guinea pigs" to workshop her drafts. She would always bring in snippets of things that would eventually turn into larger pieces. So yeah, that advantage is something pretty special and again that is almost like a jazz band. That is not a classical thing. When you have a group, you are bringing in tunes. You bring in stuff. Everyone is contributing. Its might not be something that you play tomorrow, but it would be later. I think part of her process was to utilize us as a think tank group in order to turn something into a larger piece later on.

So, a quiet space. Yeah, she would speak about from time to time. She would talk about the need for that and sort of the noise that is in your mind as a composer. You can't turn off those ideas when they come. You just have to hope that they will stay and come back again or that you will be able to act upon it. So, I think not being in the group has freed up that time to listen to those voices and ideas. It's a leap of faith to leave something that you been involved with for so many years, but that opens up a new door. As of lately, she has had these incredible 
commissioning happening, so the deadline was there. Then it is a matter of the clock. As a composer, you do get into that world too. You just gotta meet deadlines. You write because you need to, so you gotta find the space. Of course, the results are always brilliant. 


\section{APPENDIX D \\ PUBLISHED WORKS OF VALERIE COLEMAN}

\section{ORCHESTRAL}

Umoja, Anthem for Unity (2019)

commissioned by the Philadelphia Symphony Orchestra

Phenomenal Women (2018)

commissioned by Carnegie Hall \& American Composer Orchestra

The Painted Lady (2005)

commissioned by The Hartford Symphony Orchestra

\section{CONCERT BAND}

Arabia (2013)

UMOJA (2008)

ROMA (2009)

\section{$\underline{\text { SOLO/DUO }}$}

Fanmi Imèn (2018)

fl, pno

commissioned by the 2018 National Flute Association

Wish Sonatine (2015)

fl, pno

commissioned by Virginia Polytechnic Institute and State University with support from Elizabeth Crone and Dr. Richard Masters with The College of Liberal Arts and Human Sciences Diversity Grant

Danza de la Mariposa (2008)

solo fl

Sonatine (2005)

cl, pno

Legends (2005)

fl, pno

written for the Kentucky Flute Society 


\section{$\underline{\text { CHAMBER MUSIC }}$}

Shotgun Houses (2018)

$\mathrm{cl}$, string quartet

Revelers (2018)

fl, ob, cl, bn, hn, vl, vla, vln, db, pno

commissioned by Decoda Artists

Hair, Cloth and Thread (2017)

$\mathrm{fl}$ (w/picc, alto or bass, or contrabass $\mathrm{fl}$ ) and percussion commissioned by Aark Duo

A Right to Be (2017)

fl, cl, bn, pno

Bronzeville (2017)

wind sextet

Rubispheres \#4 (2015)

bn, alto sax

Migration (2015)

two vln

Freedmen (2015)

fl (db.alto), cl, vln, vcl, pno

Rubispheres (2015)

fl, cl, bn

Goin' Uptown (2015)

Flute choir and soloist

Elegy (2015)

flute ensemble and soloist

JUBA (2014)

flute choir

written for NFA High school Flute Choir

Trio Toccato (2014)

ob, bn, pno

Ruby St. Nola (2012)

flute trio 
Tzigane (2011)

wind quintet

Four Winds of Ol'Forester (2011)

$\mathrm{fl}$, vln, vc, tape

Pontchartrain (2011)

flute choir

Our God of Voiceless Things (2009)

oratorio for choir, wind quintet, and jazz ensemble

commissioned by Saint Peter's Church, NY

Fire Dance (2009)

flute choir

Red Clay and Mississippi Delta (2009)

wind quintet

NONET (2008)

wind quintet \& string quartet

Des Filmes Epiques (2008)

wind quintet \& string quartet

Lenox Ave. (2007)

cl, vln, vla, pno

commissioned by The Brooklyn Philharmonic

Suite: Portraits of Langston (2007)

Fl (picc), cl, pno, opt. Narrator

commissioned by The Flute/Clarinet Duos Consortium

Maombi Asante - A Prayer of Thanksgiving (2006)

$\mathrm{fl}$, vln, vc - commissioned by Blackledge Music, Inc

Suite: Portraits of Josephine (2006)

fl, ob, cl, bn/sop. sax, hn, kit, perc

Suite: Portraits of Josephine (2006)

wind quintet 

UMOJA (2003)
flute choir
woodwind trio (fl,ob,cl)
flute trio
brass quintet
string quartet

speech. and canzone (2002)

wind quintet $\&$ mp4

Afro-Cuban concerto (2001)

wind quintet

UMOJA (2001)

wind quintet 


\section{APPENDIX E}

\section{AWARDS \& DISCOGRAPHY}

\section{AWARDS AND HONORS}

Aspen Music Festival Wombwell Kentucky

Michelle E. Sahm Memorial Award

Van Lier Fellowship

Multi-Arts Production (MAP) Fund

Herb Alpert Award in the Arts

ASCAP Honors Awards

National Academy of Recording Arts and Sciences

Chamber Music America's Classical Commissioning Program

The Academy of Arts and Letters

United States Artists

$\underline{\text { RECORDINGS }}$

2018 Edward Simon: Sorrows and Triumphs

2013 Wayne Shorter Quartet: Without a Net

2013 Mohammed Fairouz: Native Informant

2012 Chick Corea: The Continents

2010 Terra Incognita

2008 This Christmas with Imani Winds

2008 Brubeck Brothers Quartet: Classified

2007 Josephine Baker: A Life of le Jazz Hot

2006 Imani Winds 
2005 The Classical Underground

2005 Grammy Nomination for Best Classical Crossover Album

2002 Umoja

2001 Steve Coleman: The Ascension to Light 


\section{APPENDIX F \\ COPYRIGHT PERMISSION REQUEST: THEODORE PRESSER COMPANY}

October 16, 2019

Brittany Trotter

\section{Re: Dissertation Permission}

Dear Brittany:

Carl Fischer, LLC, on behalf of the Theodore Presser Company (the "Owner"), hereby grants to you (the "Licensee") non-exclusive permission to include the following musical compositions entitled Fanmi Imen and Wish Sonatine for Flute and Piano (the "Musical Compositions") by Valerie Coleman in your dissertation ("Dissertation") to West Virginia University. The Dissertation is to be published by West Virginia University and ProQuest on the following terms:

Term: $\quad$ Perpetuity

Media: Distribution through West Virginia University and ProQuest

Fee: $\quad$ Thirty Dollars $(\$ 30.00)$

The copyright notices, as they appear in the Musical Compositions, shall appear in any written materials associated with the Dissertation.

Please sign and return one copy of this agreement.

Carl Fischer, LLC

o/b/o Theodore Presser Company

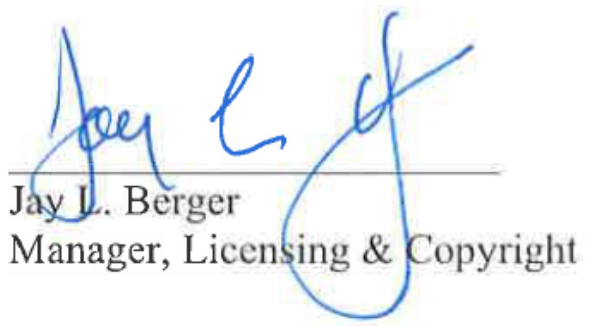

\section{Brittany Trotter}

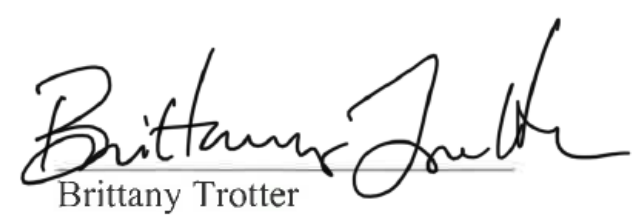




\section{APPENDIX G \\ COPYRIGHT PERMISSION REQUEST: PENGUIN RANDOM HOUSE}

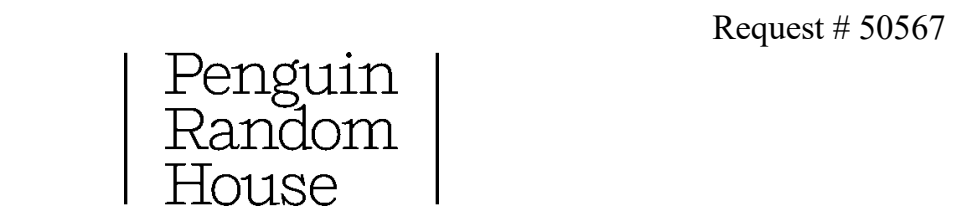

Permissions Department, 1745 Broadway, New York, NY 10019
$\begin{array}{lr}\text { Telephone: } 855-278-8634 & \text { Fax: } 212-572-6066\end{array}$

Email: permissions@penguinrandomhouse.com

November 06, 2019

Brittany Trotter

bmt0005@mix.wvu.edu

RE: "Human Family" from I SHALL NOT BE MOVED by Maya Angelou

Dear Brittany Trotter:

We have no objection to your use of the above material in your dissertation, as requested in your letter of $10 / 30 / 2019$, subject to the following conditions:

- Such material must be reproduced exactly as it appears in our publication;

- Full acknowledgment of the title, author, copyright and publisher must be given (please use credit line below);

Permission extends to the prospective publication of your dissertation by WVU Dissertations, and by ProQuest through its ProQuest ${ }^{\circledR}$ Dissertation Publishing business. ProQuest may produce and sell copies of your dissertation on demand and may make your dissertation available online for free download at your request, provided a credit line* is run. ProQuest may not use, sell, make available online, or distribute our material separately or apart from your dissertation as a whole.

${ }^{*}$ Credit line:

"Human Family" from I SHALL NOT BE MOVED by Maya Angelou, copyright (c) 1990 by Maya Angelou. Used by permission of Penguin Random House LLC. All rights reserved.

Best wishes for the success of your paper.

$r$.

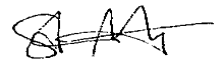

Sherri Marmon, Senior Manager, Permissions Penguin Random House LLC smarmon@penguinrandomhouse.com

212-572-2606 


\section{COPYRIGHT PERMISSION REQUEST: CARCANET PRESS LIMITED}

CARCANET PRESS LIMITED

4th Floor, Alliance House

30 Cross street

Manchester

M2 7AQ

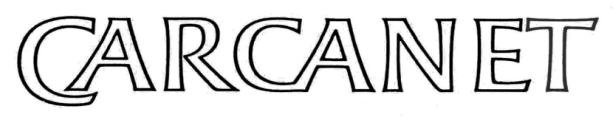

AT Reg No: 158247938

Telephone: (+44) 01618348730

Email: accounts@carcanet.co.uk

Proforma

Page 1

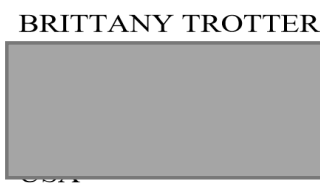

\begin{tabular}{|l|c|}
\hline Invoice No. & 21161 \\
\hline Invoice/Tax Date & $03 / 12 / 2019$ \\
\hline Cust. Order No. & \\
\hline Account No. & TROTTERB \\
\hline
\end{tabular}

Author

FRED D'AGUIAR

THE ROSE OF TOULOUSE

Title of Extract

'WISH'

FULL POEM ONLY

To be reprinted/broadcast in

'DMA DISSERTATION'

ONLINE PUBLICATION ONLY

For the following Territories

USA ONLY 


\section{BIBLIOGRAPHY}

\section{BOOKS AND BOOK CHAPTERS}

Agawu, Kofi. The African Imagination In Music. New York: Oxford University Press, 2016.

Acheraiou, Amar Acheraiou. Questioning Hybridity, Postcolonialism and Globalization. Houndmills: Palgrave Macmillan, 2011.

Angelou, Maya. I Shall Not Be Moved. New York: Random House, 1990.

Auner, Joseph. Music in the Twentieth and Twenty-Frist Centuries. New York: W.W. Norton and Company, 2013.

Bakhtin, Mikhail. The Dialogic Imagination: Four Essays. Austin: University of Texas Press, 1981.

Beard, David and Kenneth Gloag. Musicology: The Key Concepts. London: Routledge, 2016.

Born, Georgina Born and David Hesmondhalgh. Western Music and Its Others: Difference, Representation, and Appropriation in Music. Berkeley: University of California Press, 2000.

Brah, Avar and Annie Coombes. Hybridity and Its Discontents: Politics, Science, Culture. London: Routledge, 2000.

D’Aguiar, Fred. The Rose of Toulouse. Manchester: Carcanet Press, 2013.

Du Bois, W.E.B. The Souls of Black Folk: Essays and Sketches. Charlottesville, VA: Generic NL Freebook Publisher, 1996.

Hargreaves, David, Dorothy Miell, and Raymond MacDonald. Musical Identities. Oxford: Oxford University Press, 2002.

Kraidy, Marwan M. Hybridity, or the Cultural Logic of Globalization. Philadelphia: Temple University Press, 2005.

Lawson, Colin and Robin Stowell. The Cambridge History of Musical Performance. Cambridge: Cambridge University Press, 2012.

Syrotinski, Michael. Deconstruction and the Postcolonial: At the Limits of Theory. Cambridge: Liverpool University Press, 2017.

Young, Robert Young. Colonial Desire: Hybridity in Theory, Culture, and Race. London: Routledge. 1995. 
Lawrence Kramer, "Musical Meaning: Toward a Critical History," (Berkeley: University of California Press, 2001), 11.

\section{GROVE, ENCYCLOPEDIAS, AND DICTIONARIES}

Alisdair Roger, Noel Castree, and Rob Kitchin, "Hybridity." A Dictionary of Human Geography. Oxford University Press, 2013. DOI:

10.1093/acref/9780199599868.001.0001.

Brown, Maurice J.E, Eric Sams, and Robert Winter "Schubert, Franz." Grove Music Online. Oxford University Press: 2001. DOI: https://doiorg.www.libproxy.wvu.edu/10.1093/gmo/9781561592630.article.25109.

Buchanan, Ian. "Hybridity." In A Dictionary of Critical Theory. 2nd ed. Oxford University Press, 2018. DOI: 10.1093/acref/9780198794790.001.0001.

Burkholder, Peter J, James B. Sinclair, and Gayle Sherwood Macgee. "Ives, Charles." Grove Music Online. Oxford University Press: October 16, 2013. DOI: https://doiorg.www.libproxy.wvu.edu/10.1093/gmo/9781561592630.article.A2252967.

Garden, Edward. "Five, the." Grove Music Online. Oxford University Press: 2001. DOI: https://doi-org.www.libproxy.wvu.edu/10.1093/gmo/9781561592630.article.09765.

Goldschmitt, Kariann ."Hybridity." In The Grove Dictionary of American Music Online. $2^{\text {nd }}$ ed. Edited by Charles Hiroshi Garrett. Oxford University Press, 2013. DOI: 10.1093/acref/9780195314281.001.0001.

Griffin, Gabriele. "Identity." In A Dictionary of Gender Studies. $1^{\text {st }}$ ed. Oxford University Press, 2017. DOI: 10.1093/acref/9780191834837.001.0001.

Jeanes, Emma. "Identity." In A Dictionary of Organizational Behavior. $1^{\text {st }}$ ed. Oxford University Press, 2019. DOI: 10.1093/acref/9780191843273.001.0001.

Anderson, Ray C. "Hybridity." In Berkshire Encyclopedia of Sustainability. Berkshire Publishing Group, 2010. DOI: 10.1093/acref/9780190622664.001.0001.

Mayhew, Susan. "Hybridity." In A Dictionary of Geography. Oxford University Press, 2015. DOI: 10.1093/acref/9780199680856.001.0001.

Pritchett, James, Laura Kuhn, and Charles Hiroshi Garrett. "Cage, John." Grove Music Online. Oxford University Press, July 10, 2012. DOI: https://doiorg.www.libproxy.wvu.edu/10.1093/gmo/9781561592630.article.A2223954.

Scott, John. "Hybridity." In A Dictionary of Sociology. 4" ed. Oxford University Press, 2014. DOI: $10.1093 /$ acref/9780199683581.001.0001. 
Vivanco, Luis A “Identity." In A Dictionary of Cultural Anthropology. $1^{\text {st }}$ ed. Oxford University Press, 2018. DOI: 10.1093/acref/9780191836688.001.0001.

. "Hybridity." In A Dictionary of Cultural Anthropology. $1^{\text {st }}$ ed. Oxford University, 2018. DOI: 10.1093/acref/9780191836688.001.0001.

Walsh, Stephen. "Stravinsky, Igor." Grove Music Online. Oxford University Press, 2001. DOI: https://doi-org.www.libproxy.wvu.edu/10.1093/gmo/9781561592630.article.52818.

\section{JOURNAL ARTICLES}

Benson, Sheila Benson. "'I Don't Know If That'd Be English or Not': Third Space Theory and Literacy Instruction." Journal of Adolescent \& Adult Literacy 53, no. 7 (2010): 555-556.

Friedman, Johnathan. "The Hybridization of Roots and the Abhorrence of the Bush." In Spaces of Culture: City, Nation, World, edited by Mike Featherstone and Scott Lash, 230-256, Theory, Culture \& Society. London: SAGE Publications Ltd, 1999. DOI: 10.4135/9781446218723.n13.

Kim, Jin-Ah Kim. "Cross-Cultural Music Making«: Concepts, Conditions and Perspectives." International Review of the Aesthetics and Sociology of Music 48, no. 1 (2017):19-32.

Locke, Ralph Locke, "On Exoticism, Western Art Music, and the Words We Use." Archiv Für Musikwissenschaft 69, no. 4 (2012): 318-328.

Meyer, Eve R. "Turquerie and Eighteenth-Century Music.” Eighteenth-Century Studies 7, no. 4 (1974): 474-488. DOI:10.2307?3031600.

Pasler, Jann. "Theorizing Race in Nineteenth-Century France: Music as Emblem of Identity." The Musical Quarterly 89, no. 4 (2006): 459-504.

Perl, Benjamin. "Mozart in Tukey." Cambridge Opera Journal 12, no. 3 (November 2000): 219-235.

Pieterse, Jan Nederveen. "Globalization and Culture: Three Paradigms." Economic and Political Weekly 31, no. 23 (June 8, 1996):1389-1393.

Ravel, Maurice. “Contemporary music.” Rice Institute Pamphlet - Rice University Studies 15, no 2 (1928): 131-145.

Ringer, A.L. “On the Questions of 'Exoticism' in 19 $19^{\text {th }}$ Century Music.” Studia Musicologica Academiae Scientiarum Hungaricae 7, no. 1/4 (1965): 115-123. DOI:10.2307/901419. 
Shankar, S. “The Origins and Ends of Postcolonial Studies.” Ariel 30, no. 4 (October 1999): 143155.

Smyth, Willie. Review of Cosmopolitansim: Ethics in a World of Strangers, by Kwame Anthony Appiah, Western Folklore 68, no. 1 (2009): 78-80.

Stross, Brian. "The Hybrid Metaphor: From Biology to Culture. " The Journal of American Folklore 112, no. 445 (1999): 254-267. DOI:10.2307.541361.

Taylor, Timothy D. "Some Versions of Difference: Discourses of Hybridity in Transnational Music." In Global Currents: Media and Technology Now, edited by Oren Tasha G. and Petro Patrice, 219-244. New Brunswick: Rutgers University Press, 2004.

Wegman, Rob C. “Another 'Imitation' of Busnoys's 'Missa L’Homme armé- And Some Observations of 'Imitatio' In Renaissance Music." Journal of the Royal Musical Association 114, no. 2 (1989): 189-202.

Westbook, Peter. "Valerie Coleman: Revitalizing the Woodwind Quintet." Flutist Quarterly 33, no. 3 (Spring 2008): 36-39.

\section{DISSERTATIONS AND THESES}

Alcalde, Bruno Moschine. "Patterns of Hybridity: An Analytical Framework for Pluralist Music." PhD diss., Northwestern University, 2017.

Geels, Jessica Geels.“Tools for storytelling: Exploring the Compositional Techniques Crumb Employs in "Vox Balaenae."'DMA Diss., California State University, 2015.

Issac, Carol Gertrud. "The Solo Flute Music of Three Contemporary Flutist/Composers: Robert Aitken, Robert Dick, and Harvey Sollberger.” DMA diss., University of California, 1991.

Ohtake, Noriko. "Creative Sources for the Music of Toru Takemitsu.” DMA Diss., University of Maryland, 1990

Robinson, Elizabeth."Voice, Itinerant, and Air: A Performance and Analytical Guide to the Solo lfute Works of Toru Takemitsu.” DMA Diss., Ball State University, 2011.

\section{NEWSPAPER ARTICLES}

Brown, Joel. "Once a BU Tanglewood Institute Student, Alum Valerie Coleman Returns as Visiting Artist," BU Today, July 16, 2019. http://www.bu.edu/articles/2019/once-a-butanglewood-institute-student-alum-valerie-coleman-returns-as-visiting-artist/. 
Coleman, Valerie. “Classical Chamber Music Ensemble Imani Winds.” By Ed Gordon. NPR News \$ Notes. May 23, 2006.

"Grammy Nominated Flutist/Composer Valerie Coleman Joins Frost School of Music." University of Miami News. August 6, 2018. https://news.miami.edu/frost/stories/2018/08/grammy-nominated-flutist-composervalerie-coleman-joins-frost-school-of-music.html.

Holmes, Annie Holmes. "Hear it at the Library: The Orpheus Chamber Orchestra Performs a New Work Inspired by Maya Angelou's "Phenomenal Woman"," Library of Congress, May 20, 2019. https://blogs.loc.gov/catbird/2019/05/hear-it-at-the-library-the-orpheuschamber-orchestra-performs-a-new-work-inspired-by-maya-angelous-phenomenalwoman/.

Midgette, Anne. "The top 35 Female Composers in Classical Music," The Washington Post, August 4, 2017. https://www.washingtonpost.com/entertainment/music/the-top-womencomposers-in-classical-music/2017/08/04/319274d4-76f2-11e7-803fa6c989606ac7_story.html.

Ross, Brad S. “American Composers Orchestra at Zankel Hall,” Oberon's Grove, November 7, 2018. https://oberon481.typepad.com/oberons_grove/2018/11/american-composersorchestra-zankel-hall.html.

Sawyier, Tim. "Imani Winds Close First UC Season with Homage to Gwendolyn Brooks." Chicago Classical Review, May 4, 2017.

https://chicagoclassicalreview.com/2017/05/imani-winds-close-first-uc-season-withhomage-to-gwendolyn-brooks/.

Women's History Month Spotlight: Valerie Coleman.” University of Miami News, March 7 , 2019. https://news.miami.edu/frost/stories/2019/03/valerie-coleman-womens-month.html.

\section{SCORES}

Coleman, Valerie. Fanmi Imèn, Malven: Theodore Presser Company, 2018.

Coleman, Valerie. Wish Sonatine.Malven: Theodore Presser Company, 2015.

\section{SOUND RECORDING}

Begay, Heidi Kay. “An Interview with Valerie Coleman.” December 8, 2018. In Flute 360, episode 37. Podcast, MP3. 40:33. http://heidikaybegay.libsyn.com/episode-37-aninterview-with-valerie-coleman. 
Coleman, Valerie. "FNMC Presents: Interview with Valerie Coleman.” Interview by Karen Large. Flute New Music Consortium, November 17, 2018. Video, 18.59. https://www.youtube.com/watch?v=t-ZUu86SP-8..

Massoud, Caity. "Valerie Coleman.” January 15, 2019. In Flute Unscripted. Podcast, MP3, 30:55. https://player.fm/series/flute-unscripted/valerie-coleman.

\section{WEBSITES}

Braatz, Thomas. “The Quodlibet as Represented in Bach's Final Goldberg Variation BWV 988/30." Last modified January 2005. https://www.bachcantatas.com/Articles/BWV988-Quodlibet[Braatz].htm.

Brown, Elizabeth. "Trillium.” Accessed October 22, 2019. http://elizabethbrowncomposer.com/ music/trillium/.

Clarke, Ian Clarke. “TRKs.” Accessed October 22, 2019. http://ianclarke.net/page22.html.

Coleman, Valerie "A Right to Be for Flute, Clarinet, Bassoon and Piano (2017)," Chamber Music Northwest. Accessed October 13, 2019. https://cmnw.org/music/valerie-coleman/.

. "Biography," Accessed October 30, 2019.

https://www.vcolemanmusic.com/about.html.

. "Red Clay \& Mississippi Delta for Wind Quintet." Accessed September 20, 2019. https://www.vcolemanmusic.com/store/p1/Red_Clay_\%26_Mississippi_Delta_ for_Wind_Quintet_\%28Digital_Download\%29.html.

. "Work." Accessed on October 30, 2019. https://www.vcolemanmusic.com/works.html.

Coleman, Valerie (VC Page), "Dear FB Friends and Family, I have Big News to Share." Facebook post, October 1, 2018. https://www.facebook.com/VALERIECOLEMANPAGE/posts/10155876025086033.

Corigliano, John "Pied Piper Fantasy (1982).” Accessed October 22, 2019, http://www.johncorigliano.com/index.php/index.php?p=item $2 \& s u b=$ cat\&item=29.

Imani Winds. “About,” Last Modified August 2019. http://www.imaniwinds.com/bio. ."2019 Festival.” Accessed October 14, 2019. http://www.imaniwindsfestival.com/IWCMF/ABOUT.html. 
Marciniak, Katarzyna. "The Postcolonial And The Postmodern: Homi Bhabha." Accessed September 15, 2019.

http://homepage.westmont.edu/hoeckley/readings/symposium/pdf/201_300/218.pdf.

Riley, Terry, Willie Williams, and Blake Marie Bullock. "Sun Rings (2002)." Kronos Quartet. Last modified October 22, 2018. https://kronosquartet.org/projects/detail/sun_rings.

Imani Winds, "Imani Winds: Terra Incognita," interview by Frank J. Oteri.

\section{INTERVIEWS}

Coleman, Valerie. Interview by Brittany Trotter. November 24, 2019.

Ellis, Monica. Interview by Brittany Trotter. October 28, 2019. 